\title{
Medievalista
}

\section{A serpente, espelho de Eva}

Iconografia, analogia e misoginia em fins da Idade Média

The serpent, mirror of Eve. Iconography, analogy and misogyny in the end of the Middle Ages

\section{Hilário Franco Júnior}

\section{OpenEdition \\ Journals}

\section{Edição electrónica}

URL: http://journals.openedition.org/medievalista/2840

DOI: $10.4000 /$ medievalista.2840

ISSN: 1646-740X

\section{Editora}

Instituto de Estudos Medievais - FCSH-UNL

\section{Refêrencia eletrónica}

Hilário Franco Júnior, «A serpente, espelho de Eva », Medievalista [Online], 27 | 2020, posto online no dia 01 janeiro 2020, consultado o 10 dezembro 2020. URL : http://journals.openedition.org/ medievalista/2840 ; DOI : https://doi.org/10.4000/medievalista.2840

\section{(c) (†) \&}

Mediavalista está licenciado com uma Licença Creative Commons - Atribuição-NãoComercial 4.0 Internacional. 
Título / Title (Português e Inglês): A serpente, espelho de Eva. Iconografia, analogia e misoginia em fins da Idade Média / The serpent, mirror of Eve. Iconography, analogy and misogyny in the end of the Middle Ages

Autor(es) / Author(s): Hilário Franco Júnior

Afiliação institucional / Institutional affiliation (Universidade, Faculdade, Departamento ou Unidade de Investigação / University, Faculty, Department or Research Centre): Departamento de História, Faculdade de Filosofia, Letras e Ciências Humanas, Universidade de São Paulo

Código postal / Postcode; Cidade / City; País / Country: 05508-900 São Paulo, Brasil Email Institucional / Institutional email: hilario.franco-jr@wanadoo.fr ORCID: https://orcid.org/0000-0003-1519-180X

Fonte: Medievalista [Em linha]. Direc. Bernardo Vasconcelos e Sousa. Lisboa: IEM. Disponível em:

http://www2.fcsh.unl.pt/iem/medievalista/MEDIEVALISTA27/hilario2705.html ISSN: 1646-740X

DOI : 10.4000/medievalista.2840

Data de recepção do artigo / Received for publication: 1 de Março de 2019

Data de aceitação do artigo / Accepted in revised form: 24 de Julho de 2019 


\section{Resumo}

$\mathrm{Na}$ vasta iconografia medieval do Pecado original, durante muito tempo prevaleceu a fórmula Adão e Eva em lados diferentes da Árvore proibida, com a serpente voltada para a mulher. Nos séculos XIII-XV uma inovação conheceria grande sucesso: a serpente que induz Eva ao pecado passou várias vezes a ser figurada com feições femininas. Como para o historiador não deve haver factos inexplorados, por mais irrelevantes que pareçam à primeira vista, este artigo é uma tentativa de explicação da razão de ser daquelas imagens. A hipótese apresentada resulta da articulação de três elementos fortes na visão de mundo da época: a linguagem imagética, a argumentação analógica e a prática misógina.

Palavras-chave: Eva, Serpente, Iconografia, Analogia, Misoginia.

\section{Abstract}

In the vast medieval iconography of the original Sin, the formula Adam and Eve on different sides of the Forbidden Tree, with the serpent facing the woman prevailed for a long time. In the thirteenth-fifteenth centuries an innovation would have great success: the serpent that induces Eve to sin has often been figured with feminine features. As for the historian there should be no unexplored facts, as irrelevant as they may seen at first glance, this article is an attempt to explain the purpose of those images. The hypothesis presented results from the articulation of three strong elements in the world view of that time: imagery language, analogical argumentation and misogynistic practice.

Keywords: Eve, Serpent, Iconography, Analogy, Misogyny. 


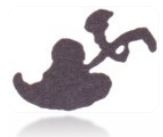

\section{A serpente, espelho de Eva. Iconografia, analogia e misoginia em fins da Idade Média / The serpent, mirror of Eve. Iconography, analogy and misogyny in the end of the Middle Ages}

\section{Hilário Franco Júnior}

Bem menos dotado fisicamente que outros animais, o homo fundou sua sobrevivência no gregarismo, e para tanto no desenvolvimento ao longo de sua evolução de diferentes modalidades de comunicação: gestual, sonora, verbal, imagética e escrita. Todas essas linguagens trabalham com formas e estruturas cuja finalidade é transmitir significações, ou seja, são sistemas semióticos possuidores de seus próprios vocabulários, semânticas, sintaxes, figuras de retórica, gramáticas e pragmáticas. A linguagem iconográfica, que aqui nos interessa, não é diferente, lida com signos, formas que revestem conteúdos atribuídos por convenção de cada comunidade. Por exemplo, "leão" em qualquer língua e em qualquer figuração plástica não é uma coisa em si, é algo que está no lugar de outro. É uma imagem, uma representação (imago é imitação, cópia, simulacro, aparência, fantasma, sonho, visão, retrato, estátua) de algo existente para além dela, mas associado a ela.

Algo que torna presente uma realidade ausente ao retirar o modelo de seu plano temporal, passado ou futuro, para torná-lo contemporâneo ao observador. Algo que estabelece sincronicidade entre o modelo e sua figuração. Logo, imago é mais do que simples imitação, é transferência de algo de uma instância para outra. É estímulo para melhor pensar o modelo, é muitas vezes a única forma de alcançá-lo. Daí no Ocidente cristão medieval, independentemente de local e época, as imagens terem servido em especial para materializar realidades transcendentes. Como Deus é eternamente contemporâneo de todos os homens, uma imagem plástica d'Ele permitia tornar cada homem 
contemporâneo de Deus. Como Ele está em todas as partes, e sempre, a rigor não haveria necessidade de figurá-lo em pedra, madeira, metal, vidro, pergaminho ou papel, a não ser para colocar homem e Divindade num mesmo plano de comunicação possível. Funcionalmente, toda imagem era expressão, por participação na essência, de eventos e personagens que se encontravam fora do alcance do observador.

Trata-se, portanto, de mecanismo indutivo, aquele que permite passar do particular (cada imagem) ao geral (o modelo da imagem) graças a uma operação mental analógica. Se tanto a intelecção analógica como a lógica são intemporais, são instrumentos utilizados pelo homem pelo menos desde o Paleolítico superior, não se pode negar que essa realidade antropológica conhece flutuações de intensidade conforme o campo de atuação humana considerado ou a época estudada. No que diz respeito ao Ocidente, a interpretação analógica do mundo foi essencial na larga etapa pré-cartesiana, quando predominou aquilo que Philippe Descola chama de "analogismo", ontologia do fracionamento, da individuação e da recomposição dos seres e das coisas ${ }^{1}$.

O mais claro testemunho disso foi o cristianismo, que ao mesmo tempo expressou e reforçou o recurso ao pensamento analógico ao ver correspondências estreitas entre eventos e personagens do Antigo e do Novo Testamento. Mesmo no interior de cada livro bíblico ocorrem relações de simetria, similitude, paralelismo, como Deus utilizar o limo da terra (âdâhmah, humus) para formar o homem (âdhâm, homo). Por argumentação analógica, a Virgem era pensada como um tabernáculo que guardou a mais preciosa das relíquias, Cristo, daí algumas estátuas dela abrirem-se mostrando no interior a cena da Crucificação. Da mesma maneira que o coalho vem do leite e o queijo do coalho, explica Hildegarda de Bingen em meados do século XII, a semente masculina recebida pela

\footnotetext{
${ }^{1}$ DESCOLA, Philippe - "Manières de voir, manières de figurer". in DESCOLA, Philippe (dir.) - La fabrique des images. Visions du monde et formes de la représentation. Paris: Musée du Quai Branly / Somogy, 2010, p. 14. Em trabalhos anteriores, o mesmo antropólogo, professor no Collège de France, já tinha mostrado como povos "que não pensam como nós" fundam sua visão de mundo em analogias entre homens, plantas, animais e pedras: La Nature domestique. Symbolisme et praxis dans l'écologie des Achuars. Paris: Maison des Sciences de l'Homme, 1996; Par-delà nature et culture. Paris: Gallimard, 2005. Foi isso que tentamos demonstrar em relação à civilização medieval em dois artigos, FRANCO JÚNIOR, Hilário - "Modelo e imagem. O pensamento analógico medieval". in FRANCO JÚNIOR, Hilário - Os três dedos de Adão. Ensaios de mitologia medieval. 2a ed. São Paulo: Edusp, 2010, pp. 93-128; e, FRANCO JÚNIOR, Hilário - "Similibus simile cognoscitur. O pensamento analógico medieval". Medievalista 14 (julho-dezembro 2013). [Em linha]. [Consultado a 18 Setembro 2019]. Disponível em http://www2.fcsh.unl. pt/iem/medievalista/MEDIEVALISTA14/junior1402.html.
} 
mulher está de início sob a forma de leite, depois de coalho, por fim de carne ${ }^{2}$, o mesmo arrazoado que explica a etimologia de formaggio e fromage, derivadas do latim medieval formaticum, literalmente "coisa formada".

O habitus ${ }^{3}$ mental da analogia e o cultural da iconografia não poderiam deixar de se repercutir no habitus social da misoginia, bem enraizado no Ocidente medieval apesar de variável conforme os tempos e espaços. Não é despropositado considerar que o progresso do culto mariano, a partir do século XII, geralmente interpretado pela historiografia como indício de recuperação da imagem da mulher, talvez comportasse também outro entendimento, pois Maria mais do que mulher, parecia aos medievais ser a negação da essência do feminino: ela não foi fecundada por homem, não pariu com dores, não teve vida sexual. Tanto que a versão cortesã do marianismo, a poesia trovadoresca dos séculos XII-XIII com sua aparente exortação da mulher, não rompeu o profundo antifeminismo medieval, como Howard Bloch convincentemente mostrou ${ }^{4}$.

Essas rápidas observações indicam a necessidade de estender as considerações sobre o pensamento analógico e a misoginia medievais ao campo da iconografia, mesmo se a rigor isso não pode ser realizado de maneira sistemática e serial nos limites de um curto ensaio e dentro das possibilidades de um pesquisador isolado. Em razão disso, restringimo-nos aqui, a título de sondagem pontual, a um único tema, por várias razões essencial para o homem medieval - o do Pecado original. Ainda assim, por haver várias centenas de representações iconográficas daquele evento mítico, recortamos nosso campo de observação a um tipo específico de figuração, aquele no qual aparece a serpente prosopogino $^{5}$. Como o rol destas imagens, algumas dezenas de exemplares, permanece

\footnotetext{
${ }^{2}$ BINGEN, Hildegardis de - Causae et curae. Ed. Paul Kaiser. Leipzig: Teubner, 1903, II, p. 109, linhas 20-21.

${ }^{3}$ Termo que a partir de Aristóteles e Cícero os medievais utilizavam para designar uma disposição adquirida e que tornada permanente, acrescentada à substância humana, modifica-a, revela-se uma qualidade anímica que permite ao homem agir tendo em vista certa finalidade: TOMÁS DE AQUINO - Suma teológica, I-II, pp.49-54, Vol. IV. Ed. Leonina, trad. e dir. Gabriel Galache e Danilo Mondoni. São Paulo: Loyola, 2015, pp. 37-93.

${ }^{4}$ BLOCH, Howard - Medieval Misogyny and the Invention of Western Romantic Love. Chicago: Chicago University Press, 1991; POWER, Eileen - Medieval Women [1975]. Cambridge: Cambridge University Press, 1997, já havia chamado atenção para o fato de o amor cortesão ter sido mais importante na literatura do que na vida (pp. 20 e 28).

${ }^{5}$ Propomos este neologismo para indicar a serpente com rosto (antepositivo "prosopo", do grego prósōpon, pessoa, personagem, rosto) de mulher (pospositivo "gino", de guné, gunaikós, mulher), cf. indicações do
} 
amplo para o presente trabalho, centramos os comentários em um único espécime (fig. 1), obra do ativo (deve-se a ele umas trezentas obras, um terço das quais em latim, dois terços em francês) gravador e editor parisiense Antoine Vérard (1450?-1519) para uma Bíblia $^{6}$ que publicou em fins do século XV ou princípios do seguinte ${ }^{7}$.

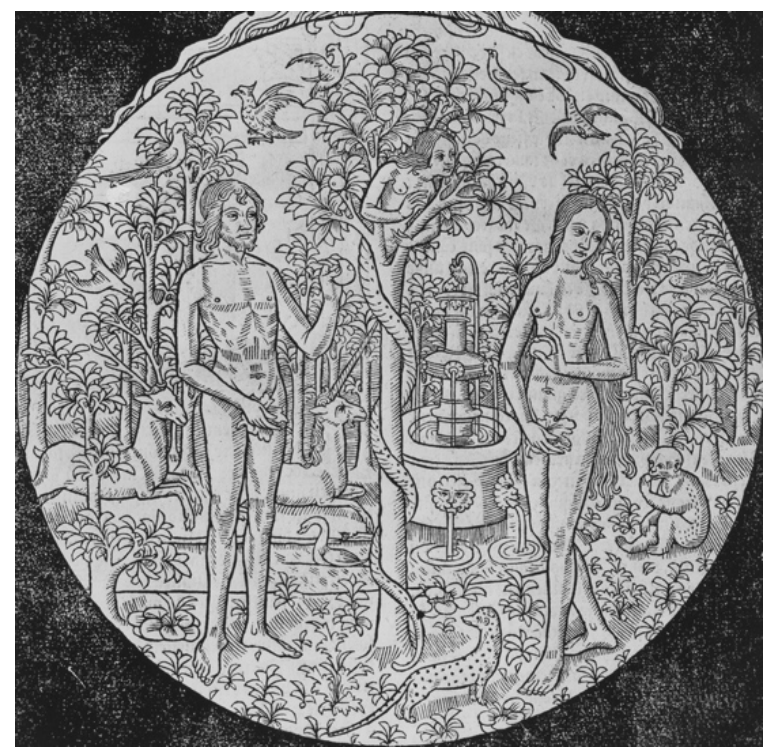

Fig. 1 - O Pecado original, c. 1505, Bible en francoiz historiee. Vol.I. Paris: Vérard, fol. II ${ }^{8}$.

Grande Dicionário Houaiss da Língua Portuguesa. Vol. IV e V. Lisboa: Círculo de Leitores, 2015, p. 1989 e p. 3164. (respectivamente).

${ }^{6}$ Da Bible en francoiz historiee [1505?] são conhecidos atualmente três exemplares, enquanto da Bible en françois hystoriée [c.1510] eles são oito, cf. FOURNIÉ, Eléonore - "Catalogue des éditions de la Bible historiale". L'Atelier du Centre de Recherches Historiques. Revue électronique du CRH 03.2 (2009) [Em linha]. [Consultado a 18 Setembro 2019]. Disponível em http://journals.openedition.org/acrh/1839. A esta listagem deve-se acrescentar ao menos cópias presentes em coleções particulares e, no caso do primeiro título, a do Metropolitan Museum of Art de Nova Iorque (Harris Brisbane Dick Fund, 1924, 24.16.1), no do segundo a do mesmo museu (Elisha Whittelsey Fund, 1951, 51.548).

${ }^{7}$ A data não vem indicada no livro, sendo então objeto de especulações. CLAUDIN, Anatole - Histoire de l'imprimerie en France au $X V^{e}$ et $X V I^{e}$ siècle. Vol. II. Paris: Imprimerie Nationale, 1901, pp. 481-482, considera aquela gravura anterior a 1499; JANSON, Horst W. - Apes and Ape Lore in the Middle Age and the Renaissance. Londres: Warburg Institute-University of London, 1952, p. 124, afirma que ela é de mais ou menos de 1499; TOMPKINS, Ptolemy - O Macaco na Arte [1994], trad. Isabel Motta. Lisboa: Quetzal, 1994, reproduz o exemplar do Metropolitan Museum datando-o de c.1500 (p. 32), enquanto o site do museu fala em c.1501 [Em linha] [Consultado a 18 Setembro 2019]. Disponível em https://www.metmuseum.org/art/ collection/search/338311. O exemplar da Bibliothèque Nationale de France (BnF), Rés. G-A-22, é datado pela instituição de c.1505. De seu lado, MACFARLANE, John Antoine Vérard [1900]. Genebra: Slatkine, 1971, p. 78, acredita que a edição é de cerca de 1510, o que é desmentido pelo fato de a gravura ter sido reaproveitada no Mistère du viel testament que Pierre Le Dru imprimiu para Vérard por volta de 1506, cf. JANSON, Horst W. - Apes and Ape Lore ..., p. 143, n.62. A mais recente avaliação, de FOURNIÉ, Eléonore - "Catalogue des éditions de la Bible historiale" ..., propõe 1505 .

${ }^{8}$ BnF, Rés G-A-22, fol. 2, gravura reaproveitada nas reedições de 1510 (BnF, A-273) e 1514 (BnF, A-274 e BnF-Arsenal FOL-T-142 [Em linha] [Consultado a 8 Setembro 2019]. Disponível em https:// gallica.bnf.fr/ark:/12148/bpt6k1518990n/f29.image. O exemplar do Met também é acessível online, no

Medievalista № 27 | Janeiro - Julho 2020 ( IEM - Instituto de Estudos Medievais 6 www2.fcsh.unl.pt/iem/medievalista 


\section{As relações analógicas}

A referida cena foi articulada em torno de quatro grandes relações analógicas. A primeira entre Eva e a serpente, esta voltada para a mulher e representada com as mesmas feições que ela, criando assim uma relação especular e por conseqüência certa identidade entre as duas personagens. A inspiração inicial teve a sua origem num apócrifo do século IV, que em suas diversas versões afirmava que assim como para se ensinar um papagaio a falar coloca-se um espelho diante da ave e fala-se atrás dele, o demônio tinha assumido a forma feminina para levar Eva a comer o fruto proibido ${ }^{9}$. A ideia foi aproveitada numa passagem atribuída a Beda (e não identificada pela erudição moderna) ${ }^{10}$, a partir de cuja autoridade foi aceite por respeitáveis autores dos séculos XII-XIV acessíveis a Vérard.

Foi o caso de, em 1169-1170, Pedro Comestor, professor da escola catedralícia de Paris; um pouco antes de 1187, Estevão Langton, que havia ensinado teologia naquela cidade e viria a ser arcebispo de Canterbury; por volta de 1214, Gervásio de Tilbury, clérigo inglês que estivera ao serviço do arcebispo de Reims em fins da década de 1180; nos anos 1230, o belga Tomás de Cantimpré, hagiógrafo e enciclopedista dominicano que estudou em Paris em fins daquela década, e de cuja obra muito se serviu em torno de 1244 o igualmente dominicano Vicente de Beauvais, preceptor dos filhos do rei Luís IX; em 1287, o juiz siciliano Guido delle Colonne; por volta de 1324, o anônimo e popular Speculum humanae salvationis; entre 1362 e 1387, William Langland no seu bem difundido Piers the Plowman ${ }^{11}$. Como quer que seja, o hibridismo de duas espécies

endereço citado na nota anterior. A gravura em questão foi especialmente confeccionada para aquela edição (cf. CLAUDIN, Anatole - Histoire de l'imprimerie en France..., Vol. II, p. 482).

${ }^{9}$ La caverne des trésors. Version géorgienne, IV, 8-14. Ed. Ciala Kourcikidzé, trad. Jean-Pierre Mahé. Louvain: Peeters, 1992, p. 8; La caverna dei tesori, 16. Ed. Margaret Dunlop Gibson, trad. Antonio Battista e Bellarmino Bagatti. Jerusalém: Franciscan Priting Press, 1979, p. 43; La caverne des trésors. Les deux recensions syriaques, IV, 6-12. Ed. Carl Bezold, trad. Su-Min Ri. Louvain: Peeters, 1987, pp. 12-15.

${ }^{10}$ BONNELL, John K. - "The Serpent with a Human Head in Art and in Mystery Play". American Journal of Archaeology 21 (1917), p. 257, n.3, sugere uma deformação de transcrição ou de leitura de "velut organum" em "vultum virgineum" em passagem das Quaestiones super Genesim (PL 93), col. 276c, atribuídas a Beda.

${ }^{11}$ COMESTOR, Pedro - Historia scholastica (PL 198), Liber Genesis, 21, col. 1072b; LANGTON, Estevão - Expositio litteraris in Historia scholastica, BnF, Ms. lat. 14417, fol. 129v citado por KELLY, Henry A. - "The Metamorphoses of the Eden Serpent during the Middle Ages and Renaissance". Viator 2 (1971), n. 38, p. 309; TILBURY, Gervásio de - Otia imperialia, I, 15. Ed. - trad. Shelagh E. Banks e James W. Binns. Oxford: Clarendon, 2002, p. 86; CANTIMPRÉ, Tomás de - De natura rerum, British Museum, Ms. Egerton 1984, fol. 93v (citado por KELLY, p. 323, n.99); BEAUVAIS, Vincent de - Speculum naturale, XX, 33. Graz: Akademische Druck- u. Verlagsanstalt, 1964, col. 1478e (onde cita Tomás de Cantimpré) e XXX, 68, cols. 2265e-2266a (onde cita Pedro Comestor); COLONNE, Guido della - Historia 
diferentes, típica do "modo de figuração analógico"12, revela os pontos comuns que se pensava haver entre o anjo-réptil e a fêmea humana, embora não esclareça quem é o modelo, quem é a imagem.

A segunda associação analógica na gravura de Vérard ocorre entre Eva e o macacohomem pois, haviam explicado dois textos do século XII, aquele animal em latim é simius devido à sua similitudo com o ser humano ${ }^{13}$. Na imagem em questão, ele é um modelo para o Pecado por se tratar de um simia Dei, uma representação do Diabo tanto para descrições literárias ${ }^{14}$ como iconográficas ${ }^{15}$. Por decorrência, é imagem antecipada do ser humano pós-Queda, imitação degradada do que este tinha sido no Éden ${ }^{16}$. Exemplo

destructionis Troiae, 10. Ed. Nathaniel E. Griffin. Cambridge (Mass.): Medieval Academy of America, 1936, p. 97; Speculum humanae salvationis I, 14. Ed. Jules Lutz e Paul Perdrizet. Mulhouse: Meininger, 1907, vol. I, p. 4 (latim) e 122 (tradução francesa de Jean Miélot, em 1448); LANGLAND, William de The Book Concerning Piers the Plowman, 18. Ed. Rachel Attwater, trad. Donald e Rachel Attwater. Nova Iorque: Dutton, 1957, p. 175.

${ }^{12}$ DESCOLA, Philippe - "Un monde enchevêtré". in DESCOLA, Philippe (dir.) - La fabrique des images..., pp. 165-172.

${ }^{13}$ SAINT-VICTOR, Pseudo-Hugo de - De bestiis (PL 177), II, 12, col. 62d; The Bestiary. A book of beasts. Trad. Terence H. White. Nova Iorque: Putnam, 1960, p. 34. No século VII, SEVILHA, Isidoro de Etimologías, XII, 2, 30. Ed. Wallace M. Lindsay, trad. José Oroz Reta e Manuel-Antonio Marcos Casquero. Madrid: BAC, 2009, pp. 906-909, já registrara a existência dessa interpretação, que ele considera falsa. Fundamentando a aproximação entre homem e macaco, um dos argumentos usados desde a mais antiga versão latina que conhecemos de um texto (fins do século IV) muito difundido ao longo da Idade Média era a ausência de rabo no macaco (Physiologus latinus. Versio B, XXI,12. Ed. Francis J. Carmody. Paris: Droz, 1939, p. 38), informação repetida por quase todos os bestiários medievais. Para uma visão de conjunto da questão, JANSON, Apes and Ape Lore..., pp. 73-106.

${ }^{14}$ Physiologus latinus, XXI, p. 38; SAINT-VICTOR, Pseudo-Hugo de - De bestiis, II, 12, col. 63a; THAUN, Philippe - Le bestiaire, vv 1901-1902. Ed. Emmanuel Walberg. Rungis: Maxtor, 2017, p. 70; BEAUVAIS, Pierre de - Bestiaire. in Bestiaires du Moyen Age, trad. Gabriel Bianciotto. Paris: Stock, 1980, p. 44; NORMANDIE, Guillaume le Clerc de - Bestiaire divin. in Bestiaires du Moyen Age..., p. 102; Le bestiaire (Oxford, Bodleian, Ms. Ashmole 1511). Trad. Marie-France Dupuis e Sylvain Louis. Paris: Philippe Lebaud, 1988, p. 68. Em função do caráter demoníaco do macaco, na célebre crítica que São Bernardo faz à presença de imagens figurativas nos claustros ele lembra em primeiro lugar dos "macacos imundos": Apologia ad Guillelmum abbatem, XII, 29. Ed. Jean Leclercq e Henri M. Rochais. Roma: Editiones Cistercienses, 1963 (S. Bernardi Opera, III), p. 106, linha 16.

${ }^{15}$ É o que mostra, em 1225-1235, o Psalterium dito de Branca de Castela, Bibliothèque de l'Arsenal, Ms. 1186, fols. 9v, 19v, 20, 25v, 65, 77v, 168, 169v, 170, 171 [Em linha]. [Consultado a 18 Setembro 2019]. Disponível em https://gallica.bnf.fr/ark:/12148/btv1b105065665.image. Ou, em fins do século XIV, o Speculum humanae salvationis, BnF, Ms. lat. 511, fols. 3v, 11v, 12, 13v, 21, 29v, 30v, 31v, 38v, 41v, 42 [Em linha]. [Consultado a 18 Setembro 2019]. Disponível em http:// archivesetmanuscrits.bnf.fr/ark:/12148/cc13636r. Ou ainda, na mesma época, sobre outro suporte, o capitel do Pecado original no claustro de Saint-Sever-de-Rustan (hoje no Jardim Massey, em Tarbes), no qual a serpente é representada com rosto demoníaco enquanto na outra face do capitel aparecem um macaco e um bode como tentadores-auxiliares.

${ }^{16}$ JANSON, Horst W. - Apes and Ape Lore..., pp. 107-144. CURTIUS, Ernst R. - Literatura Europeia e Idade Média Latina. Trad. Paulo Rónai e Teodoro Cabral. São Paulo: Edusp / Hucitec, 1996, pp. 655-656, fornece vários exemplos dos séculos XII-XIII do uso metafórico de simius como "imitador", inclusive um que o define como "macaco da natureza humana". Aquele animal é igualmente visto como homem 
expressivo desta interpretação encontra-se a uns cem quilômetros a sudoeste de Toulouse, na colegiada de Saint-Gaudens cuja decoração escultórica, da passagem do século XI ao XII, estabelece clara relação entre o Pecado original (capitel do lado sul do coro, face leste) e o macaco que se masturba (capitel do lado norte, face leste), imagens que Durliat atribui a um mesmo $\operatorname{artista}^{17}$.

No Saltério de Branca de Castela, animais de sentido moral positivo (cervo, cabra, boi, pássaros, peixes) cercam a cena do nascimento de Eva, enquanto na cena do trabalho dos protoplastas Adão tem à sua frente, dirigindo-lhe olhar sarcástico, um pequeno macaco que assiste ao homem a trabalhar ${ }^{18}$. Embora não conste o nome de Vérard, atribui-se a ele o Livre des Ordonnances de la prévosté des marchans et eschevinage de la ville de Paris, de 1500, cujo último fólio mostra na inicial L um pequeno macaco sentado comendo uma maçã diante de Eva, que em pé cobre a nudez com uma mão e segura o fruto na outra ${ }^{19}$. Várias vezes na escultura e na iluminura medievais um símio está associado ou mesmo identificado ao pecador ou ao próprio Diabo, caso de um relevo da Porta das Platerías (c.1120-1130), o pórtico meridional da catedral de Compostela, onde é um macaco-diabo que tenta o Cristo. Dito de outra forma, a serpente é análoga à mulher e o macaco ao homem.

Mais especificamente, o macaco devido à sua sexualidade supostamente exagerada era símbolo do comportamento humano não mais angelical como na origem, e sim aquele que se seguiu ao Pecado original, despudorado, faltoso, animalesco, diabólico em suma. Desde então ficou abolida a fronteira entre aquele animal e os humanos. Pedro Damiano conta, afirmando ter ouvido o relato do papa Alexandre II (1061-1073), que a esposa de Guilherme, conde da Ligúria, mantinha relações sexuais com um macaco que vivia na corte $^{20}$. Por isso a iconografia medieval mostra com alguma frequência um leão (símbolo cristológico) atacando um macaco (símbolo demoníaco), como exemplifica um bestiário

\footnotetext{
degradado em culturas não-cristãs da Oceania, África e América, cf. TOMPKINS, Ptolemy - O Macaco na Arte..., p. 31.

${ }^{17}$ DURLIAT, Marcel - "La collégiale de Saint-Gaudens et les origines de la sculpture romane méridionale". Comptes-rendus des séances de l'Académie des Inscriptions et Belles-Lettres 125 (1981), p. 391.

${ }^{18}$ Bibliothèque de l'Arsenal, Ms. 1186, fol. 10r, 11v e 12r.

${ }^{19}$ Imagem reproduzida em CLAUDIN, Anatole - Histoire de l'imprimerie en France.... Vol. II, p. 500.

${ }^{20}$ De bono religiosi status (PL 145), 29, cols. 789c-790a.
} 
latino copiado e iluminado entre 1225 e 1250 na Inglaterra $^{21}$. Herdeiro dessa longa tradição cultural, em várias imagens das Bíblias que editou Vérard figurou igualmente a serpente com rosto simiesco ${ }^{22}$.

Diferentemente das duas associações anteriores, que são binárias (Eva-serpente, Evamacaco), a terceira é triangular e resulta de uma recomposição delas. Este triângulo analógico domina todo o lado esquerdo da cena (direito do observador), dado simbólicoespacial que reforça sua conotação demoníaca. Do centro e do alto (apesar de tudo o Diabo é um anjo) até a parte baixa onde está o símio (bem próximo ao solo, indicativo de seu caráter material, terreno), uma linha imaginária oblíqua atravessa a cena unindo as mãos da serpente, da mulher e do macaco. Os três têm o braço em posição de noventa graus, mas a mão da serpente que estimula o gesto pecador é a direita, enquanto a mulher e o macaco seguram o fruto com a esquerda.

Desta forma, Eva é analogizada dupla e negativamente pela serpente (cujos seios e rosto feminino constituem-se em modelo para ela) e pelo macaco (que come o fruto proibido, funcionando como outro modelo). Trata-se, então, de solução iconográfica aparentada àquela de 1493-1494, na qual Eva segura a maçã diante de uma serpente com seios, rosto humano, orelhas de macaco e asas (fig. 2), fórmula usada por gravuras alemãs um pouco anteriores (fig. 3) e à qual Vérard apenas acrescentou, mas o detalhe é eloquente, o atributo símio. Também na posterior Bible en francoiz historiee de 1505, a cena da Expulsão mostra à direita, em primeiro plano, a Morte personificada, à esquerda e em segundo plano a serpente alada com rosto $\operatorname{simiesco}^{23}$.

\footnotetext{
${ }^{21}$ Oxford, Bodleian Library, Ms. Bodley 764, fol. 2 [Em linha]. [Consultado a 18 Setembro 2019]. Disponível em https://digital.bodleian.ox.ac.uk/inquire/Discover/Search/\#/?p=c $+0, t+$, rsrs +0, rsps + 10, fa + ,so + ox $\% 3$ Asort $\% 5$ Easc, scids + , pid + e6ad6426-6ff5-4c33-a078-ca518b36ca49, vi +86bee6cc-7b6944b6-b264-579f4ac6576c.

${ }^{22}$ Bible en francoiz historiee, BnF, Rés. G-A-22, fol. XLVIIIv, LIII, LXIIv; Bible en francois hystoriee, BnF, Rés. A-273, Vol. I, fol. LVIIv (porém colocado na posição do fol. Iv), Vol. II, fols. XLIIIv, LIII, LVI, LVIIV, LXI, XCIv.

${ }^{23}$ Rés. G-A-22, Vol. I, fol. Iv.
} 


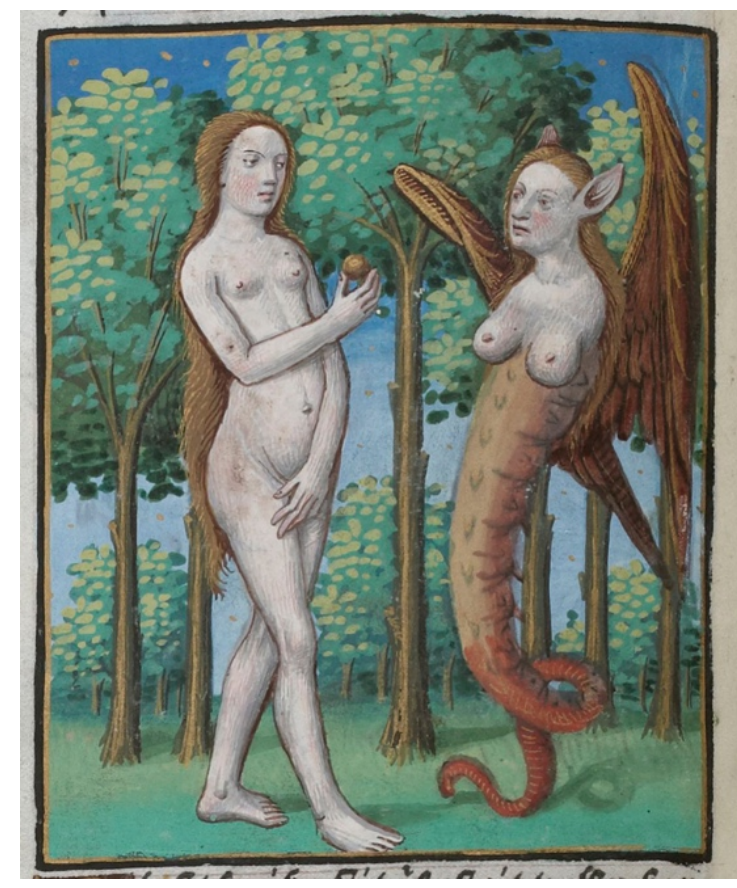

Fig. 2 - Eva e a serpente de Vérard 1493-1494, Le Mirouer de la Redemption de l'umain lignage Paris: Vérard, fol. $2 \mathrm{v}^{24}$.

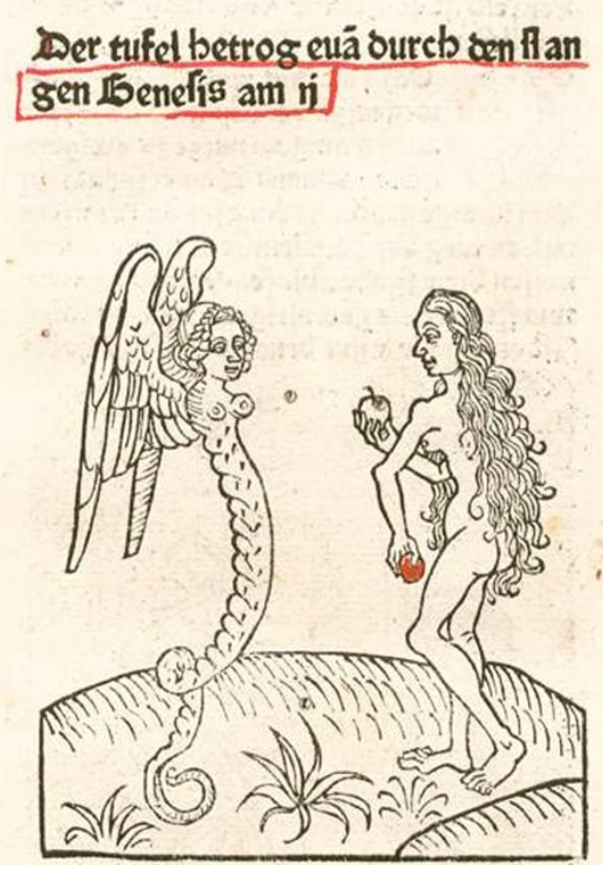

Fig. 3 - Eva e a serpente de Drach c.1480, Der Spiegel menschlicher Behältnis. Spira: s.ed. [Peter Drach], fol. 8 col. $1^{25}$.

O eixo da cena do Pecado original é a Árvore do fruto proibido, que divide a gravura em duas zonas opostas, porém complementares. À esquerda encontra-se o triângulo analógico serpente-Eva-macaco, à direita o Adão-cervo-unicórnio. Este é o triângulo claramente cristológico, como indica o significado de cada um dos personagens e, reforçando-os, da associação analógica entre eles - a quarta de nossa análise. Da mesma maneira que no primeiro triângulo o vértice é constituído pela serpente, no outro o vértice é Adão, personagem de caráter especular como Eva, contudo de sentido positivo: enquanto criatura ele é imagem de Cristo, que por sua vez enquanto encarnado é imagem do primeiro homem. Entende-se, então, que o artista tenha colocado à direita de Adão o cervo, de função salvadora inegável para a cultura medieval ${ }^{26}$. Daí por que o primeiro

24 [Em linha] [Consultado a 18 Setembro 2019] Disponível em https://gallica.bnf.fr/ark:/12148/btv1b8626772v/f14.image. Há imagem com a mesma estrutura semântica e narrativa na Bible en francois hystoriee (da qual subsistem 22 exemplares, entre eles BnF, Rés. A-270), fol. VIII, obra que veio à luz entre maio de 1498 e outubro de 1499, cf. WINN, Mary B. - Anthoine Vérard. Parisian publisher, 1485-1512. Genebra: Droz, 1997, p. 122.

25 [Em linha] [Consultado a 18 Setembro 2019]. Disponível em http://daten.digitale-sammlungen.de/ bsb00031715/image 17.

${ }^{26}$ Exemplos desse simbolismo são encontráveis em períodos variados: na primeira metade do século $\mathrm{V}$, LYON, Eucário de - Liber formularum spiritalis intelligentiae (PL 50), 5, col. 751c; no século IX, Physiologus latinus, XXIX, p. 51; na primeira metade do XII, SAINT-VICTOR, Pseudo-Hugo de - De 
remédio indicado por Pedro Hispano contra a epilepsia - doença da alma para uma autora cristã de meados do século XII, doença de humanos concebidos no repouso do sabá para um texto judaico de fins do XIII ${ }^{27}$ - é chifre de cervo pulverizado e ingerido com vinho ${ }^{28}$, o mais difundido dos símbolos cristológicos.

Do outro lado de Adão encontra-se o unicórnio. É interessante notar que desde o século II - com o célebre e difundido Physiologus, depois acompanhado por muitos outros, entre eles Orígenes, Agostinho, Philippe de Thaun, o pseudo-Hugo de Saint-Victor, um anônimo da abadia de Revesby, um anônimo de Oxford e Brunetto Latini - o caçador de serpentes era o cervo ${ }^{29}$, mas na gravura de Vérard devido à identidade simbólica profunda com o unicórnio, aquele animal parece ter transmitido a este a tarefa de atacar a Tentadora enrolada na Árvore. Com efeito, é o chifre do unicórnio que toca o corpo da serpente, reafirmando o bem familiar sentido cristológico daquele animal ${ }^{30}$.

Na conexão entre os dois triângulos mencionados há um elemento importante, que contagia o primeiro com traços do segundo. Trata-se da pequena pantera, símbolo de Cristo por ser definida em alguns textos como "inimiga do dragão"31, e de forma mais

bestiis, II, 14, col. 64b; em meados do XIII, VARAZZE, Jacopo de - Legenda Áurea, 156. Ed. Theodor Graesse, trad. Hilário Franco Júnior. São Paulo: Companhia das Letras, 2003, p. 894.

${ }^{27}$ BINGEN, Hildegarda de - Causae et curae, II, pp. 155-156; Zohar, 14b. Ed. Yehouda L. Achlag, trad. Charles Mopsik. Paris: Verdier, 1988, p. 91.

${ }_{28}$ Thesaurus pauperum, VII, 1. in A Obra Médica de Pedro Hispano. Ed. e trad. Maria Helena da Rocha Pereira. Coimbra: Fundação Calouste Gulbenkian / Universidade de Coimbra, 2014, pp. 104-105.

${ }^{29}$ Physiologus latinus, XXIX, 2-3, p. 50; ORÍGENES - Homélies sur le Cantique des cantiques, II, 11. Ed. Willem A. Baehrens, trad. Olivier Rousseau. Paris: Cerf, 1954, p. 98; AGOSTINHO - Enarrationes in Psalmi (PL 36), XLI, 3, col. 465; THAUN, Philippe - Le bestiaire, vv 721-732, p. 27; SAINT-VICTOR, Pseudo-Hugo de - De bestiis, II, 14, col. 64c; The Bestiary (Cambridge Ii.4.26), pp. 37-38; Le bestiaire (Ashmole 1511), p. 68; LATINI, Brunetto - Le livre du trésor, 183. Vol.I. Ed. Francis Carmody, trad. Bernard Ribémont e Silvère Menegaldo. Paris: Honoré Champion, 2013, pp. 420-421. Um exemplo iconográfico dessa ideia temos em fins do século XIII em manuscrito da obra de FOUILLOY, Hugo de Aviarium, Valenciennes, Bibliothèque Municipal, Ms.101, fol. 192.

${ }^{30}$ Apesar de algumas vezes ser símbolo do Mal - como em Salmos XXII, 22, ou no Libellus de natura animalium / Le proprietà degli animali, 29. Ed. Paola Navone, trad. Annamaria Carrega. Gênova: Costa e Nolan, 1983, p. 284 - quase sempre aquele animal é o Cristo: TERTULIANO, Adversus Judaeos, X, 7-8. Ed. Alöis Gerlo. Turnhout: Brepols, 1954 (CCSL 2), p. 1376; AUGUSTODUNENSE, Honório - Speculum de mysteriis ecclesiae (PL 172), col. 847; SAINT-VICTOR, Pseudo-Hugo de - De bestiis, II, 6, col. 59c; THAUN, Philippe - Le bestiaire, vv 393-458, pp. 15-17; NORMANDIE, Guillaume le Clerc de - Bestiaire divin, pp. 93-94; Le bestiaire (Ashmole 1511), p. 61. Mais especificamente, pensava-se que ele era figura do Cristo-juiz abrandado pela Virgem, como sugere o Physiologus latinus, XVI, p. 31.

${ }^{31}$ Physiologus latinus, XXIII, 2, p. 40, acompanhado, como era freqüente, por muitos autores, entre eles SAINT-VICTOR, Pseudo-Hugo de - De bestiis, II, 23, cols. 69-71; THAUM, Philippe - Le bestiaire, v. 461-580, pp. 18-22; BEAUVAIS, Pierre de - Bestiaire..., p. 45; LATINI, Brunetto - Le livre du trésor..., 193, pp. 450-451; LÚLIO, Raimundo - Livro das bestas, 6. Ed. Marina Gustá, trad. Cláudio Giordano. São Paulo: Loyola-Giordano, 1990, pp. 112-114. 
direta, em um bestiário inglês de fins do século XII ou princípios do XIII, Cristo é chamado de "a verdadeira pantera" 32 . Posicionada entre os pés da mulher e a extremidade da cauda da serpente, a pantera expressa a relativa recuperação social e moral da mulher que ocorria desde o século XII ao lembrar que apesar de pecadora e mãe da morte, Eva teria dentre suas descendentes aquela que seria mãe da vida e instrumento de redenção de todos os humanos. Pela mesma razão, a pantera está colocada a meio caminho entre o unicórnio (que por derivação analógica de símbolo do Cristo tornou-se também símbolo da Virgem ${ }^{33}$ ) e Eva (que ao comer o maldito fruto perdeu a humanidade, redimida pelo bendito fruto do ventre da Virgem). Aliás, é para indicar que no plano divino uma mulher deveria redimir a falta da outra, que uma iluminura francesa do século XV mostra um unicórnio na cena de nascimento de $\mathrm{Eva}^{34}$.

Acentuando a função da pantera, Vérard logo abaixo do unicórnio e ao lado de Adão figura um cisne, bem próximo à perna deste e à pata daquele. Com efeito, o sentido positivo daquela ave estava explicitado por certos textos: um bestiário do século XII garante que ela traz boa sorte, uma tradução francesa do mesmo texto comenta no começo do século XIII que o cisne "significa a alma que se alegra na tribulação", poucas décadas depois uma enciclopédia reafirma o caráter propício do cisne ${ }^{35}$.

Das quatro analogias acima descritas, a básica, que de certa forma torna as demais necessárias, é aquela estabelecida entre Eva e a serpente prosopogino. Embora sem o nível de complexidade ali presente, ela tinha vários antecedentes iconográficos desde fins do século XI e mais intensamente de princípios do XIII, com alguns dos quais Vérard pode ter tido contato, direto ou indireto. Como suas sucessivas oficinas de trabalho sempre estiveram, indicam os cólofons das obras que editou, nas imediações da Notre-

\footnotetext{
${ }^{32}$ Le bestiaire (Ashmole 1511), p. 59.

${ }^{33}$ Escrevendo entre 1121 e 1135, THAUM, Philippe - Le bestiaire, v. 433-436, p. 17, especificou que "este animal na verdade [...] significa a Virgem". Sobre os diferentes sentidos religiosos do unicórnio, EINHORN, Jürgen W. - Spiritalis Unicornis. Das Einhorn als Bedeutungsträger in Literatur und Kunst des Mittelalters. Munique: Fink, 1976. Ou, menos desenvolvido, porém útil, JOSSUA, Jean-Pierre - La licorne: histoire d'un couple. Paris: Cerf, 1985.

${ }^{34}$ Trésor de sapience, Bibliothèque do Arsenal, Ms. 5076, fol.7.

35 The Bestiary, p. 119; BEAUVAIS, Pedro de - Bestiaire. Ed. Charles Cahier e Arthur Martin. Mélanges d'archéologie, d'histoire et de littérature. Vol. III Paris: Poussielgue-Rusand, 1853, p. 233 (esta ave não aparece na redação curta do texto, traduzida por Bianciotto, cit. n.14); LATINI, Brunetto - Le livre du trésor..., 161, p. 379.
} 
Dame de Paris ${ }^{36}$, ele certamente conhecia a escultura sobre o tema em um dos pórticos da catedral. E também, a 400 metros dali, o trumeau da entrada da capela baixa da SainteChapelle (1246-1248) com seu dragão alado e de rosto feminino esculpido sob os pés da Virgem com o Menino. Outra imagem assemelhada da qual Vérard pode ter tido conhecimento, é uma escultura em madeira do norte francês (c.1400) que figura a Virgem amamentando o Menino e tendo abaixo deles Eva, que em postura serpentina come o fruto, enquanto do outro lado da Árvore interditada está a serpente com cabeça de mulher ${ }^{37}$.

Editor reputado e miniaturista de profissão, Vérard verossimilmente teve acesso a iluminuras sobre o tema presentes em manuscritos de prestígio no espaço cultural francês $^{38}$, sobretudo os mais próximos a ele no tempo ${ }^{39}$. Ademais, Eva e a serpente prosopogino frente a frente eram personagens frequentes na coeva e ativa indústria editorial alemã, cujas gravuras Vérard algumas vezes reproduziu e outras vezes nelas se inspirou. É certo que não conhecemos elos diretos entre o editor e gravador parisiense e seus colegas de além-Reno, porém a colaboração entre estes e seus correspondentes lioneses está bem estabelecida pela erudição moderna, permitindo pensar que Vérard pode ter tido acesso à produção alemã por intermédio de Lyon.

Ou mesmo em Paris, se lembrarmos que perto da oficina de Vérard estava a do alemão Thielman Kerver, que instalado na capital francesa em 1497 publicaria três anos mais tarde a versão latina de um texto alemão de grande sucesso e nela inseriu gravuras de

\footnotetext{
${ }^{36}$ A sede do "marchant libraire" Vérard esteve "sur le pont Nostre Dame" (1485-1499), depois "près Petit Pont" e na "rue Saint Jacques près Petit Pont" (1500-1501), por fim "devant la rue neuve Nostre Dame" (1503-1512), cf. MACFARLANE, John - Antoine Vérard..., pp. 30-32, 35-52.

${ }^{37}$ Esta peça, hoje em Londres, nas reservas do Victoria and Albert Museum, encontra-se reproduzida em HOFFELD, Jeffrey M. - “Adam's Two Wives". The Metropolitan Museum of Art Bulletin 26 (1968), fig. 5, p. 434.

${ }^{38}$ Dentre eles, a Bíblia de São Luís de 1226-1234 (Toledo, catedral, Ms.1, vol. 3, fol. 64), uma outra Bíblia produzida no norte francês em 1280-1290 (Londres, British Library, Add. Ms. 11639, fol. 520v), o Apocalypse en françois de 1313 (BnF, Ms. fr. 13096, fol. 83); a Bible moralisée de Philippe le Hardi, de 1402-1404 (Paris, BnF, Ms. fr. 166, fol. 3v); Les très riches heures du duc de Berry, de 1413-1416 (Chantilly, Museu Condé, Ms. 65/1284, fol. 25v); duas edições francesas de La Cité de Dieu, uma de c.1415 (BnF, Ms. fr. 21, fol. 29), outra de c.1420 (La Haye, Museum Meermanno-Westreenianum, Ms. 10 A 12, fol. 32).

${ }^{39}$ Por exemplo, uma tradução francesa de obra de Boccaccio, o Cas des nobles hommes et femmes dos arredores de 1470 (Carpentras, Bibliothèque Inguimbertine, Ms. 622, fol. 6v); o Livre des bonnes moeurs (1467) de Jacques Legrand (Roma, Biblioteca Apostolica Vaticana, Ms. Pal. lat. 1995, fol. 1); o Livre d'Heures de Louis d'Orléans (c.1490, São Petersburgo, Rossiiskaia Natsionalnaia Biblioteka, Lat. Q. v. I. 126, fol. 12v), a Histoire extraite de la Bible et Apocalypse, en français (princípio do século XV, Chantilly, Museu Condé, Ms. 28, fol. 3v).
} 
conterrâneos, inclusive uma que apresenta claras afinidades formais com aquela que Vérard faria alguns anos depois (fig. 4). Ademais, a referida tradução latina foi realizada pelo flamengo Josse Bade, que após ter vivido e trabalhado em Lyon de 1492 a 1498, mudou-se para Paris onde paralelamente à atividade de erudito exerceu também as de editor e impressor.

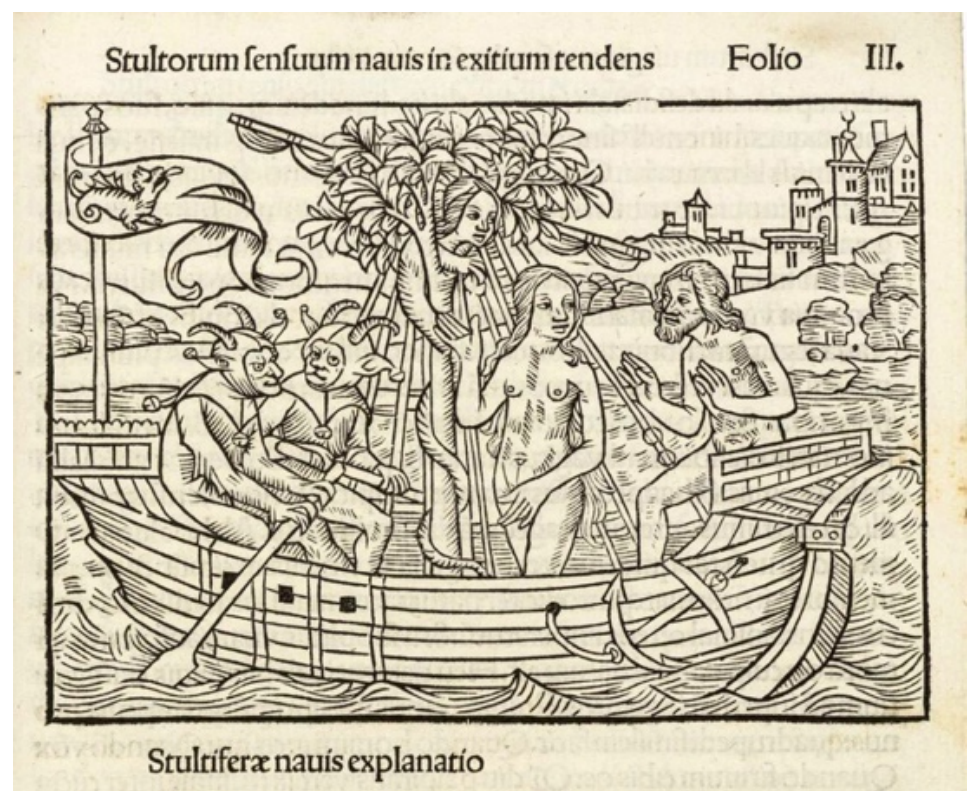

Fig. 4 - O Pecado original na nau dos loucos, 1500, Stultiferae naves sensus animosque trahentes mortis in exitium. Paris: Thielman Kerver, fol. III ${ }^{40}$.

\section{Lilith e Melusina}

Resta, porém, uma questão intrigante: porque as primeiras representações iconográficas da serpente prosopogino levaram tanto tempo a aparecer se havia referências literárias anteriores? Do ponto de vista linguístico não havia obstáculos, apesar de a denominação do réptil variar de gênero gramatical em função do arbitrário do signo linguístico (ou de algum outro componente que a psicolinguística ainda não identificou). Masculina no grego ö $\varphi ı \varsigma$, de dois gêneros no latim serpens/entis, do qual derivaram os equivalentes em francês e em provençal antigos, palavras igualmente de dois gêneros, mas também, de um

\footnotetext{
40 [Em linha $] \quad[$ Consultado a 18 Setembro 2019] Disponível em https://gallica.bnf.fr/ark:/12148/bpt6k320274m/f11.image. A edição publicada no mesmo ano em Espanha (Burgos: Fadrique Biel de Basilea, 1500) além da imagem no corpo do texto aproveitou-a também no frontispício [Em linha]. [Consultado a 18 Setembro 2019]. Disponível em http://bdhrd.bne.es/viewer.vm?id=0000176288 \&page $=1$.
} 
lado, um termo feminino em castelhano, catalão antigo, galego, português; de outro lado, masculino em francês (desde princípios do século XII e sobretudo de fins do XV), italiano, romeno. Em outro ramo indo-europeu, do proto-germânico *snakōn, masculino, $\mathrm{o}$ antigo inglês criou snaca, igualmente masculino, mas a partir do século $\mathrm{X}$ a língua foi lentamente perdendo a distinção gramatical de gêneros, processo acelerado no século XIII e completado em meados do $\mathrm{XIV}^{41}$, o que não impediu que justamente então tenham surgido naquele país imagens da serpente com rosto feminino ${ }^{42}$.

Como o texto genésico chama a serpente do Éden de "o mais ardiloso (callidus) de todos os animais", pensava-se que ela talvez fosse uma víbora (vipera), considerada por Santo Ambrósio "a mais perigosa espécie de animal e a mais astuta (astutus) de todas as serpentes" ${ }^{43}$. Ora, esse tipo de serpente é designado por uma palavra feminina em grego, latim, castelhano, catalão, francês, provençal, italiano (e dialetos como o piemontês ou o napolitano), português, galego, romeno, alemão. Esses indicativos lexicais são expressivos, mas não conclusivos, pois na época que aqui estudamos continuou forte a influência do Physiologus, que transmite um dado interessante sobre aquele réptil: até o umbigo sua aparência é humana, com o macho da espécie tendo rosto de homem e a fêmea de mulher, dali para baixo ele lembra um crocodilo $^{44}$.

Do ponto de vista mítico, havia antecedentes interessantes, cuja cronologia não permite, porém, explicar a analogia formal - o rosto feminino de Eva, o rosto feminino da serpente - adotada pela tardia iconografia cristã medieval. A partir da homofonia entre hạwwāh (Eva), hịweyā (serpente) e hịweyik (sedutor) existente no hebraico e em outras línguas semíticas, um comentário rabínico afirmara por volta do ano 320, retomando tradição anterior, que "a serpente foi tua [de Eva] serpente e tu a serpente de Adão". Ideia adotada

\footnotetext{
${ }^{41}$ JONES, Charles - Grammatical Gender in English, 950 to 1250. Londres: Croom Helm, 1988.

${ }^{42}$ Bíblia de William de Devon (meados do século XIII), British Library, Ms. Royal I.D.I, fol. 5; Saltério Carrow (meados do século XIII), Baltimore, Walters Art Gallery, Ms. W.34, fol. 22; Compendium historiae in genealogia Christi (segunda metade do século XIII), British Library, Ms. Royal Roll 14 B IX; Biblia (fins do século XIII), Oxford, Bodleian Library, Ms. Auct. D. 3. 2, fol. 133; Bíblia de Holkham (c.13201330), British Library, Add. Ms. 47682, fol. 4; Saltério de Saint-Omer (c.1330-1340), British Library, Yates Thompson Ms 14, fol. 7; Polychronicon (1375-1400), British Library, Royal 14 C IX, fol. 2v; mapa da abadia de Evesham (1390-1415), Londres, College of Arms, Muniment Room 18-19; Bedford Hours (c.1423), British Library, Add. Ms. 18850, fol. 14.

${ }^{43}$ Gênesis III,1; AMBRÓSIO - Exameron. I sei giorni della creazione, V, 7, 18. Ed. Carl Schenkl, trad. Gabrielle Banterle. Milão / Roma: Biblioteca Ambrosiana / Città Nuova, 1979, pp. 258-259.

${ }^{44}$ Physiologus, XII, p. 110: "vipera quoniam faciem habet hominis masculus, femina autem mulieris, usque ad umbilicum; ab umbilico autem usque ad caudam corcodrilli habet figuram".
} 
pelo cristianismo desde fins do século II com Teófilo de Antioquia e Clemente de Alexandria, prolongada por Eusébio de Cesareia $(† 337)$ e Epifânio de Salamina $(† 403)$, e acompanhada por muitas outras autoridades ao longo dos séculos seguintes ${ }^{45}$.

Segundo antiga tradição, atestada pelo menos desde fins do século I, a serpente foi o corpo usado por Satanás para entrar no Éden, aproximar-se de Eva e depois engravidá-la. Ou seja, o anjo caído, mais do que o réptil, é o parceiro da mulher na cena ${ }^{46}$. $O$ fato não surpreende, pois deriva de um estrato mítico pré-bíblico que deixara inegáveis resquícios no texto judaico-cristão: Joseph Campbell indicou que a serpente aparecida a Eva no jardim do Éden era uma divindade cultuada no Oriente Médio pelo menos sete mil anos antes da composição do Gênesis, divindade benéfica que podia ser representada sob forma feminina ou masculina e cujo sentido foi restringido pelo patriarcalismo da Bíblia. É para sublinhar a identidade Eva-serpente prosopogino que a literatura e a iconografia recorreram com frequência à metáfora do espelho, único meio que revela o sujeito a si mesmo ${ }^{47}$.

Assim como - afirmam dois apócrifos, um da passagem do século I ao II, outro de meados do II - Deus é o espelho no qual o homem pode se conhecer ${ }^{48}$, o Diabo é o espelho no qual a mulher pode se reconhecer. O gênero literário moralista e pedagógico do speculum, surgido no século XII para fornecer modelos de comportamento a diferentes segmentos

\footnotetext{
${ }^{45}$ A citação é do Midrach Rabba. Genèse Rabba, XX, 11 e XXII, 2. Ed. Moseh A. Mirkin, trad. Bernard Maruani e Albert Cohen-Arazi. Paris: Verdier, 1987, pp. 234 e 246. Sobre os personagens do Pecado original no pensamento cristão dos primeiros séculos, veja-se ZEEGERS-VANDER VORST, Nicole "Satan, Ève et le serpent chez Théophile d'Antioche", Vigiliae Christianae 35 (1981), pp. 152-169; PAGELS, Elaine - Adam, Eve et le serpent [1988]. Trad. Michèle Miech Chatenay. Paris: Flammarion, 1989. Ainda em 1667, MILTON, John - Paradise Lost, X, 867-868. Ed. John Leonard. Londres: Penguin, 2003, p. 240, faz Adão logo após o Pecado dirigir-se a Eva exclamando: "longe de minha vista, serpente, o nome mais adequado para ti pois estás ligada a ela".

462 Enoch, 31, 6. Ed. e trad. Francis I. Andersen. in CHARLESWORTH, James H. (ed.) - The Old Testament Pseudepigrapha, Vol. I. Londres: Darton, Longman \& Todd, 1983, p. 154. A iconografia pouco diferenciou o Diabo da serpente, os casos conhecidos são quase todos da Inglaterra do século XI ao XIV, de acordo com TRAPP, Joseph B. - "The Iconography of the Fall of Man". in PATRIDES, Constantinos A. (ed.) - Approaches to Paradise Lost. Londres: Edward Arnold, 1968, p. 241 e pp. 261-262.

${ }^{47}$ CAMPBELL, Joseph - As máscaras de Deus [1964]. Vol. III. Mitologia ocidental. Trad. Carmen Fischer. São Paulo: Palas Athena, 2004, pp. 18-24. ECO, Umberto - "Sobre os espelhos" [1985]. Trad. Helena Domingos. in ECO, Umberto - Sobre os espelhos e outros ensaios. Lisboa: Relógio d'Água, 2016, p. 21, chama atenção para o fato de que, ao contrário do que diz o senso comum, o espelho não inverte a imagem (ilusão ditada pelo ponto de percepção), apenas a expõe, sem deformação ou interpretação.

${ }^{48}$ Respectivamente, Odes of Salomon, 13, e 1. Ed. e trad. James H. Charlesworth. in The Old Testament Pseudepigrapha..., Vol. II, p. 747; Gli atti di Giovanni, 95, 20. Ed. Max Bonnet, trad. Mario Erbetta. in Gli Apocrifi del Nuovo Testamento. Vol. III. Gênova: Marietti, 1992, p. 60.
} 
sociais e profissionais, foi transposto para as artes plásticas, que insistiam na futilidade da preferência feminina pelo uso literal, não metafórico, educativo, do espelho. Sublinhando a simetria mulher-demônio, certas imagens mostram ambos com cabelo do mesmo tipo e da mesma cor, nitidamente diferenciado do de Adão ${ }^{49}$. Numa gravura feita por Dürer em 1494 para a obra de Sébastian Brant, uma mulher sentada sobre uma tábua sustentada pelo Diabo observa-se ao espelho sem perceber, diz a legenda, que se trata de uma armadilha. Três anos depois, a mesma imagem foi reaproveitada na tradução francesa da obra de Brant editada por Vérard ${ }^{50}$.

Da construção da serpente prosopogino fez parte ainda uma figura mítica judaica bem conhecida na Cristandade do século XV - Lilith. A única referência bíblica a ela identifica-a como um dos seres selvagens que invadirá a terra de Edom no dia do Juízo Final, mas isso permitia melhor compreender uma aparente incoerência do texto sagrado. Como é bem conhecido, o Gênesis afirma de início que Deus criou o ser humano macho e fêmea, presumivelmente ao mesmo tempo e da mesma matéria, contudo mais adiante narra a criação de Eva a partir de uma costela de Adão, portanto a mulher teria sido posterior e de outra matéria ${ }^{51}$. As duas passagens ficaram inteligíveis com a exegese rabínica registrada no século III, mas sem dúvida anterior, ao nelas distinguir "a primeira Eva” (personagem inominada, depois identificada com Lilith) e Eva ${ }^{52}$. O que tornou esta necessária foi a insubmissão daquela, que exigiu de Adão se acasalar deitada sobre ele $^{53}$, o que o homem rejeitou - o facto era inaceitável para as falocráticas sociedades judaica e cristã tanto do ponto vista sexual quanto simbólico - desejando então alguém feito com "osso dos meus ossos e carne da minha carne" 54.

\footnotetext{
${ }^{49}$ Entre outros exemplos, Les très riches heures du duc de Berry (c.1413-1416), fol. 25v; Bedford Hours (c.1423), fol. 14; afresco de Masolino na parede do lado direito da capela Brancacci, igreja Santa Maria del Carmine, Florença (c.1425); Cas des nobles hommes et femmes (c.1470), fol. 6v; Horae ad usum romanum (fins do século XV), BnF, Ms. lat. 1171, fol. 20v.

${ }^{50}$ BRANT, Sébastian - Das Narrenschiff. Basileia: Johann Bergmann von Olpe, 1494, fol. 122 [Em linha]. [Consultado a 18 Setembro 2019]. Disponível em rara.ch/bau_1/content/pageview/1399144; La nef des folz du monde. Trad. Pierre Rivière e Jakob Locher. Paris: Vérard, 1497, fol. 83. Milton imaginará que Eva ao nascer não buscou com o olhar o Criador, como havia feito Adão, e sim seu próprio reflexo na água clara e calma de um lago próximo, encontrando ali narcísicos "olhares de simpatia e amor": Paradise Lost, IV, 460-465, p. 85.

${ }^{51}$ Isaías XXXIV, 14; Gênesis I, 27 e II, 21-22.

${ }^{52}$ Midrach Rabba, XVII, 7, p. 202; XVIII, 4, p. 208; XXII, 7, p. 252.

${ }^{53}$ Alpha Beta Ben Sira, em Ozar Midrashim. Vol.I. Ed. Julius D. Eisenstein [1915]. Nova Iorque: E. Grossman, 1956, p. 47, citado por BITTON, Michèle - "Lilith ou la première Ève. Un mythe juif tardif". Archives de sciences sociales des religions 71 (1990), p. 119.

${ }^{54}$ Gênesis II, 23.
} 
Para tanto Deus criou Eva, o que gerou o ciúme de Lilith e seu plano de provocar a expulsão do novo casal do Éden. Visando concretizá-lo, ela associou-se ao Diabo - ele também insubmisso a Deus por ciúme de Adão ${ }^{55}$ - e assumiu a forma de serpente-mulher. O pensamento mítico marcou dessa maneira o facto de antes de Eva o homem se relacionar sexualmente com as fêmeas de todos os animais, conforme comentário do Talmude da Babilônia (c.500) ${ }^{56}$, que caracteriza Lilith como demônio alado com traços femininos e dotado de longa cabeleira ${ }^{57}$. Este mito ganharia contornos definitivos com o Alpha Beta, possivelmente do século X, retomado e desenvolvido em Castela em fins do século XIII no Zohar, que a partir da ideia de "primeira Eva" e da tradição de Eva como amante do anjo caído Samael $^{58}$, alimentou por derivação analógica a atribuição de tal condição a Lilith e a identificação entre eles ${ }^{59}$.

Nada há de estranho no facto de a iconografia da serpente feminina refletir tradições comuns às culturas judaica e cristã, que mantiveram intercâmbio frequente e estreito até o despontar do sentimento antijudaico em fins do século XI, no contexto das Cruzadas. Mesmo depois, a presença de elementos culturais hebraicos em ambientes cristãos continuou forte, como ilustra em 1169-1173 a obra de Pedro Comestor, na qual pela primeira vez aparece a menção à serpente prosopogino. Além desse autor, Pedro Cantor $(† 1197)$, Étienne Langton $(† 1228)$ e Alberto Magno $(\dagger 1280)$ também citam Lilith como a primeira Eva ${ }^{60}$. Apesar de a interdição mosaica de representar Deus ter provocado uma

\footnotetext{
${ }^{55}$ Sabedoria II, 24; 2 Enoch, 31, 3-6, p. 154; Vita Adae et Evae. Ed. Jean-Pierre Pettorelli. Turnhout: Brepols, 2012, redações V e P, §12-16, pp. 304-315 (CCSA, 18); redação E, §12-16 (CCSA, 19), pp. 577579.

${ }^{56}$ Cf. GINZBERG, Louis - The Legends of the Jews, Vol.V. Filadélfia: The Jew Society of America, 1925, p. 87, n. 39; GRAVES, Robert; PATAI, Raphaël - Les mythes hébreux [1963]. Trad. Jean-Paul Landais. Paris: Fayard, 1987, pp. 82 e 84.

${ }^{57}$ SCHOLEM, Gershom - "Lilith". in Encyclopaedia Judaica. Vol.XI. Nova Iorque: Macmillan, 1971, col. 246; BRIL, Jacques - Lilith ou la Mère obscure [1984]. Paris: Payot, 1991, p. 63; BITTON, Michèle "Lilith ou la première Ėve"..., p. 117.

${ }^{58}$ Targum du Pentateuque. Genèse, IV, 1. Ed. trad. Roger Le Déaut. Paris: Cerf, 1978, p. 101; Los capítulos de Rabbi Eliezer, XXI, 1. Ed. David Luria, trad. Miguel Pérez Fernández. Valencia: Institución San Jerónimo, 1984, p. 162; Zohar, 37a, p. 204 e 54a, p. 277.

${ }^{59}$ Textos judaicos originários da Provença do século XII já tinham visto em Lilith a companheira de Samael, cf. SCHOLEM, Gershom - Les origines de la Kabbale. Paris: Aubier-Montaigne, 1966, p. 311. A identidade entre ela e Samael foi discutida por DAN, Joseph - "Samael, Lilith, and the Concept of Evil in Early Kabbalah". Association for Jewish Studies Review 5 (1980), pp. 17-40.

${ }^{60}$ SHERESHEVSKY, Esra - "Hebrew Traditions in Peter Comestor's Historia scholastica. Jewish Quarterly Review 59 (1969), pp. 268-289; HALPERN, Catherine; BITTON, Michèle - Lilith, l'épouse de Satan. Paris: Larousse, 2010, p. 73.
} 
restrição imagética na cultura judaica e de naquela língua a palavra "serpente" (בחש, nahash) ser masculina, a serpente-mulher foi figurada em pelo menos dois manuscritos judaicos de fins do século XIII, um do sul alemão, outro do norte francês ${ }^{61}$.

Uma prova da convergência mítica judaico-cristã no que respeita a serpente com aparência de mulher encontra-se em Melusina, personagem bem conhecida em regiões de expressivas colônias judaicas, como a Provença e o Poitou ${ }^{62}$. No plano oral ela é testemunhada em torno de 1200 , mesmo que ainda inominada, por cronistas da corte inglesa que conheciam bem os territórios continentais da monarquia Plantageneta ${ }^{63}$. A partir das fontes orais surgiram os dois principais relatos literários a respeito, um em prosa, em 1393, obra de João de Arras encomendada pelo duque de Berry (em cujos domínios estava o Poitou), outro em verso, realizado por volta de 1401 pelo livreiro parisiense Coudrette a pedido do senhor de Parthenay, no norte daquela região ${ }^{64}$. Em função das inegáveis similitudes entre Lilith e Melusina é que Vicente de Beauvais pôde relatar tanto a história da serpente-mulher do Pecado original como da mulher-serpente do Poitou, ainda sem lhe atribuir um nome. Talvez seja devido às proximidades míticas entre ambas que um mesmo manuscrito, confeccionado entre 1412 e 1416 para o duque de Berry, representou-as separadas por apenas alguns fólios ${ }^{65}$.

\footnotetext{
${ }^{61}$ O primeiro reproduzido por MOSES, Elizabeth - "Über eine Kölner Handschrift der Mischneh Thora des Maimonides". Zeitschrift für bildende Kunst 60 (1926-1927), p. 74, o segundo conservado em Londres, British Museum, Add. Ms. 11.639, Miscellany, fol. 520v [Em linha]. [Consultado a 18 Setembro 2019]. Disponível em http://www.bl.uk/manuscripts/Viewer.aspx?ref=add_ms 11639 .

${ }^{62}$ Em território da atual França há 25 localidades em cujo folclore aparece Melusina, cf. FROMAGE, Henri - "Recherches sur Mélusine". Bulletin de la Société de Mythologie Française 86 (1972), p. 74.

${ }^{63}$ MAP, Gautier - Contes pour les gens de cour, IV, 9. Ed. Christopher N. L. Brooke e Roger A. B. Mynors, trad. Alan K. Bate. Turnhout: Brepols, 1993, pp. 255-257; TILBURY, Gervásio de - Otia imperialia, I, 15..., pp. 88-91 e III, 57, pp. 664-669; CAMBRAI, Geraldo de - De principis instructione, III, 27. Ed. George F. Warner. Wiesbaden: Kraus Reprint,1964, p. 301. No total, o dossiê engloba 23 textos, "abundância [que] atesta a vitalidade do tema de Melusina no imaginário medieval", constata HARFLANCNER, Laurence - Les fées au Moyen Âge. Paris: Honoré Champion, 1984, p. 120. Sobre o contexto sociopolítico do mito, LECOUTEUX, Claude - Mélusine et le Chevalier au Cygne. Paris: Payot, 1982, pp. 35-39.

${ }^{64}$ ARRAS, Jean d' - Mélusine, roman du XIVe siècle. Ed. Louis Stouff. Genebra: Slatkine, 1974; COUDRETTE - Le roman de Mélusine. Ed. Eleanor Roach, trad. Laurence Harf-Lancner. Paris: GFFlammarion, 1993. O primeiro autor afirma ter baseado sua narrativa em "crônicas autênticas" (dentre elas, verossimelmente, uma tradução francesa dos Otia imperialia, obra existente na biblioteca do duque de Berry) e nas coisas que ouviu serem contadas "aos nossos antepassados" (p. 15). O segundo reconhece que seu relato estava fundado em textos (inclusive, com certeza, o de João de Arras) e "na memória daqueles com quem falo" (p. 151).

${ }^{65}$ BEAUVAIS, Vincent de - Speculum naturale, II, 127, col. 157bc; Les très riches heures du duc de Berry, fol. 3v (Melusina) e 25v (serpente prosopogino).
} 
Com efeito, os pontos comuns entre as duas figuras são claros. Seus mitos surgiram contemporaneamente, talvez no século $\mathrm{X}^{66}$. Assim como Lilith, cujo nome pode derivar do sumério lulti, "lascívia", foi feita de argila e por essa dupla razão era uma deusa da fecundidade e da terra, pensa Jacques Bril, Melusina "aparece como o avatar medieval de uma deusa-mãe, como uma fada da fecundidade", avalia Jacques Le Goff ${ }^{67}$. Assim como Lilith, desgostosa com a recusa de Adão em aceitar a igualdade entre eles, proclamou o nome de Deus, ganhou asas e voou para longe, Melusina sentindo-se traída pelo marido que a vira durante o banho apesar do interdito combinado entre eles, saltou pela janela do castelo de Lusignan (levantado no século X, quando surgiu o mito de Melusina, isto é, de Mère Lusigne, "mãe dos Lusignan”) no qual viviam e, transformada em serpente de cinco metros de comprimento, saiu voando ${ }^{68}$.

Assim como desde a rejeição Lilith grita sua revolta, sendo conhecida por "demônio que guincha", Melusina de tempo em tempo voa perto de seu antigo castelo soltando suspiros profundos e gritos dolorosos ${ }^{69}$. Assim como Lilith é a própria serpente que assume forma de mulher, Melusina é mulher transformada em serpente da cintura para baixo como punição por desobediência à fada sua mãe. Assim como Lilith é muito fecunda, gera pelo menos cem filhos demônios por dia, Melusina teve dez filhos homens. Assim como Lilith

\footnotetext{
${ }^{66}$ A datação do mito de Lilith não é consensual: século VIII para BASKIN, Judith R. - The Cambridge Dictionary of Judaism and Jewish Culture. Nova Iorque: Cambridge University Press, 2011, p. 11; século IX ou X para LÉVI, Israel - "Lilit et Lilin". Revue des études juives 68 (1914), pp. 15-21; século X de acordo com BITTON, Michèle - "Lilith ou la première Ève"..., p. 119; século XI segundo BRIL, Jacques - Lilith..., p. 70. Quanto a Melusina, o primeiro texto foi escrito na abadia de Claraval entre 1187 e 1194 (AUXERRE, Gofredo de - Super Apocalypsim, 15. Ed. Ferruccio Gastaldelli. Roma: Edizioni di storia e de letteratura, 1970, pp. 186-187, linhas 107-133), mas os fatos míticos ali narrados teriam ocorrido pelo menos dois séculos antes, isto é, meados do século X, cf. FROMAGE, Henri - "Recherches sur Mélusine"..., p. 42. As origens da personagem são, contudo, pré-cristãs e extra-europeias como se reconhece há muito: CROSS, Tom P. - "Celtic Elements in Lanval and Graelent". Modern Philology 12 (1915), pp. 4-5.

${ }^{67}$ BRIL, Jacques - Lilith..., p. 128; LE GOFF, Jacques - "Mélusine maternelle et défricheuse" [1971]. in LE GOFF, Jacques - Pour un autre Moyen Âge. Paris: Gallimard, 1977, p. 326. Ademais, é preciso lembrar que na cultura cristã a Mãe-Terra confundia-se muitas vezes com a luxúria, cf. LECLERCQ-KADANER, Jacqueline - "De la Terre-Mère à la Luxure. À propos de la migration des symboles". Cahiers de Civilisation Médiévale 18 (1975), pp. 37-43.

${ }^{68}$ Alpha Beta Ben Sira, p. 47; ARRAS, Jean d' - Mélusine, roman du XIVe siècle..., pp. 255, 257-259; COUDRETTE - Le roman de Mélusine..., p. 106.

${ }^{69}$ GASTER, Theodor H. - Myth, Legend and Custom in the Old Testament. Nova Iorque: Harper, 1975, p. 579; ARRAS, João de - Mélusine, roman du XIVe siècle ..., pp. 258-259, 281; COUDRETTE - Le roman de Mélusine..., p. 106.
} 
vinga-se de Adão matando recém-nascidos humanos ${ }^{70}$, Melusina sequestra crianças que passam pelas suas terras. Assim como Lilith é o espelho de Eva em algumas representações iconográficas (fig. 3 e 6), Melusina é às vezes mostrada penteando sua longa cabeleira diante de um espelho ${ }^{71}$. Assim como Lilith, também Melusina ficará até o Juízo Final exilada pelos ares ${ }^{72}$.

Não parece casual, portanto, que o editor suíço Bernhard Richel tenha, em 1474, publicado uma gravura de Melusina e dois anos depois uma de Lilith face a Eva. A primeira (fig. 5) mostra a fada de rosto feminino, seios nus, asas e corpo de serpente da cintura para baixo, na segunda o demônio feminino diferencia-se apenas por estar em posição vertical ${ }^{73}$. Ou, como havia figurado um pouco antes outra publicação alemã, Lilith podia portar coroa em vez de chapéu (fig. 6). Também não é ocasional que Anton Sorg, de Augsburgo, tenha publicado três imagens da serpente-mulher bíblica em 1476 e 1479, e em 1485 uma da fada serpentina que sai voando de seu castelo ${ }^{74}$.

\footnotetext{
${ }^{70} \mathrm{Na}$ tradução latina da Vulgata o nome Lilith é substituído por lamia, termo que na mitologia grecoromana designava uma amante de Zeus que perdeu todos os filhos devido à perseguição de Hera e tornouse por isto sequestradora de crianças.

${ }^{71}$ Estátua do século XI que pelos seios lançava água na fonte do castelo de Vouvant, no Poitou (cf. Bulletin de la Société de Mythologie Française 51 (1963), p. 92); relevo no lintel da lareira de uma casa do século XV, em Lusignan (reproduzida por CLIER-COLOMBANI, Françoise - La fée Mélusine au Moyen Âge. Images, mythes et symboles. Paris: Le Léopard d'Or, 1991, fig. 68); relevo do século XV na fachada de uma casa de La Ferté-Bernard, a meio caminho entre Poitiers e Paris (CLIER-COLOMBANI, Françoise La fée Mélusine..., fig. 65); mais um relevo, da mesma época, em Bayeux, na chamada Casa de Adão e Eva (CLIER-COLOMBANI, Françoise - La fée Mélusine ..., fig. 67). Na literatura, a versão de JOÃO DE ARRAS descreve Melusina penteando os cabelos no banho (Mélusine, roman du XIV siècle, p. 230), mas nada fala de espelho, enquanto a versão de Coudrette no episódio do banho sabático da fada (Le roman de Mélusine, p. 89) não faz referência nem ao cabelo nem ao espelho.

${ }^{72}$ ARRAS, Jean d' - Mélusine, roman du XIV siècle..., pp. 248, 252; COUDRETTE - Le roman de Mélusine..., p. 104.

${ }^{73}$ Spiegel menschlicher Behaltnis. Basileia: Bernhard Richel, 1476, fol. 2 [Em linha]. [Consultado a 18 Setembro 2019]. Disponível em https://www.e-rara.ch/bau_1/ch15/content/titleinfo/2401823.

${ }^{74}$ Spiegel menschlicher Behaltnis (1476), fols. 2 e 3; Von Etlichen Frowen (1479; tradução do De claribus mulieribus, de Boccaccio), fol. 1; Melusine (1485; tradução da obra de Coudrette realizada em 1456 pelo suíço Thüring von Ringoltingen), fol. 73.
} 


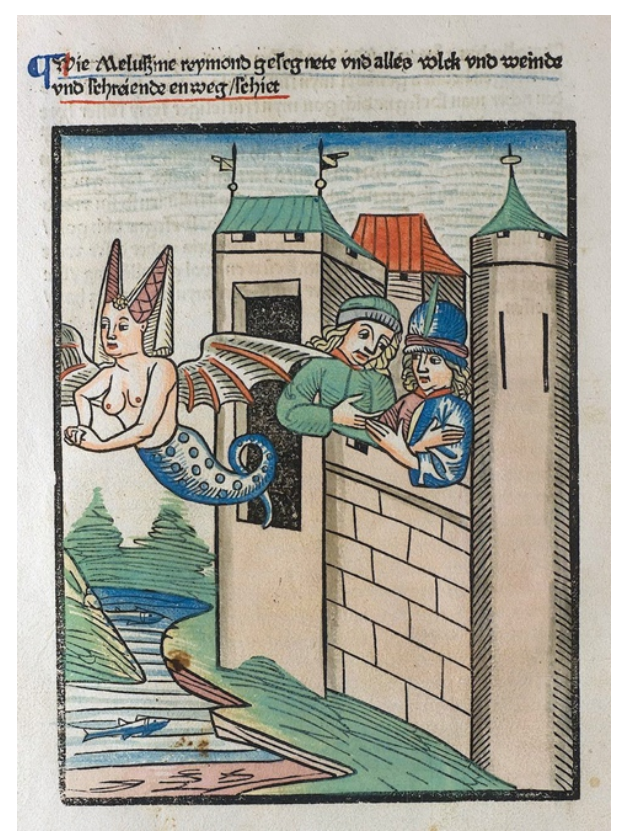

Fig. 5 - Melusina, 1476, Thüring von Ringoltingen, Melusine. Basileia: Bernhard Richel, 1476, fol. $62 \mathrm{v}^{75}$.

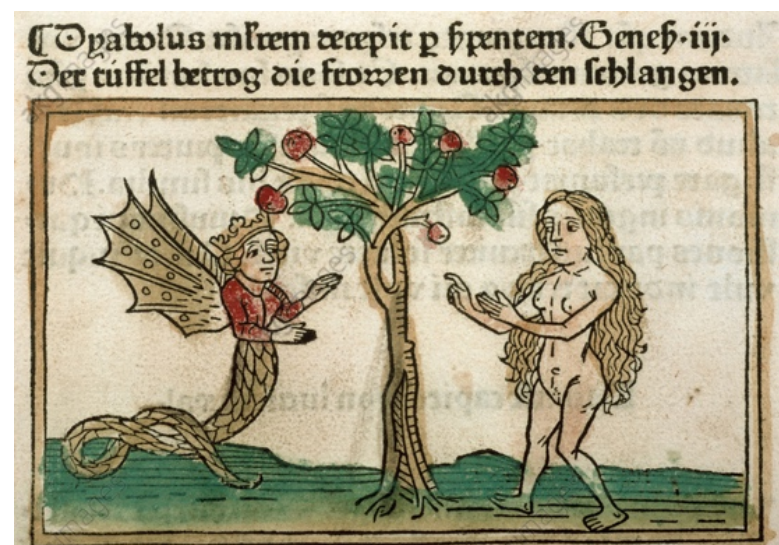

\section{గullâ fentiret infirmitatê vlegrituoî̉. Sine gemi:}

Fig. 6 - Lilith, c. 1473, Speculum humanae salvationis. Augsburgo: Günther Zainer, fol. $11^{76}$.

Por intermédio da personagem mais antiga, a outra articulava-se igualmente com Eva. O banho que Melusina tomava aos sábados já foi associado à tradição judaica do banho purificador $^{77}$ e pode ser aproximado ainda ao banho penitencial de Eva começado no oitavo dia do Exílio, isto é, num sábado se considerarmos que ela e Adão foram expulsos do Éden numa sexta-feira ${ }^{78}$. Melusina deu a seu marido dez filhos, da mesma forma que

75 [Em linha]. [Consultado a 18 Setembro 2019]. Disponível em http://tudigit.ulb.tudarmstadt.de/tmp/pdf/inc-iv-94.pdf. Esta imagem foi estudada por RAUTENBERG, Ursula - "Die 'Melusine' des Thüring von Ringoltingen und der Basler Erstdruck des Bernhard Richel'. in SCHNYDER, André; RAUTENBERG, Ursula - Thüring von Ringoltingen Melusine (1456). Nach dem Erstdruck Basel: Richel um 1473/74. Vol. II. Wiesbaden: Reichert, 2006, pp. 61-99. As gravuras de Richel influenciaram incunábulos produzidos em outros países, inclusive franceses, cf. ZELDENRUST, Lydia - "Serpent or Half-Serpent? Bernhard Richel's Melusine and the Making of a Western European Icon". Neophilologus 100 (2016), pp. 19-41.

76 [Em linha]. [Consultado a 18 Setembro 2019]. Disponível em http://daten.digitalesammlungen.de $/ 0003 / \mathrm{bsb} 00031706 /$ images $/$ index.html? fip $=193.174 .98 .30 \& \mathrm{id}=00031706 \&$ seite $=25 \mathrm{~A}$ coroa utilizada por Lilith era provavelmente referência ao fato de ela ter sido a primeira esposa de Adão, que um comentário rabínico do século II havia considerado "rei do Éden" (The Fathers According to Rabbi Nathan. Abot de Rabbi Nathan Version B, I, 8. Ed. Solomon Schechter, trad. Anthony J. Saldarini. Leiden: Brill, 1975, p. 36), ideia aceita no Ocidente cristão, como testemunha TILBURY, Gervásio de - Otia imperialia, I, 10, pp. 66-67.

${ }^{77}$ CLIER-COLOMBANI, Françoise - La fée Mélusine au Moyen Âge..., pp. 158-161.

${ }^{78}$ Il combattimento di Adamo. Ed. e trad. Antonio Battista e Bellarmino Bagatti. Jerusalém: Franciscan Printing Press, 1982, §20, p. 66; §23, p. 73. 
Eva, "mãe dos viventes", procriou de Adão muitos filhos e filhas ${ }^{79}$. Enquanto Melusina propiciou prosperidade às terras do marido, a primeira mulher embora apareça na iconografia quase sempre a fiar, era imaginada como representação das forças naturais, como uma mãe-terra cristianizada ${ }^{80}$. Se Eva não foi construtora como Melusina, que levantou vários castelos e igrejas nos domínios de Raymondin, seu primogênito, Caim, foi o primeiro a erguer uma cidade ${ }^{81}$. Ambas personagens deploraram um fratricídio entre seus filhos: Caim matou Abel, Geoffrey dos Dentes Grandes incendiou o mosteiro onde estava seu irmão Fromont ${ }^{82}$.

\section{Misoginia}

No entanto, a própria ressurgência e fortalecimento dos dados míticos precisam ser explicados. Continua em aberto a questão essencial, colocada acima: porque a ideia da serpente com cabeça de mulher, conhecida desde os primeiros tempos do cristianismo, só se difundiria no plano iconográfico a partir do século XIII? Antes disso, que saibamos, o motivo aparece apenas num capitel do coro da igreja Sainte-Croix, em Oleron SainteMarie (sudoeste francês, fins do século XI), no friso da fachada ocidental da catedral de Nîmes (c.1100), em um modilhão do lado sudeste da cabeceira da igreja abacial de Arthous, perto de Bayonne (c.1150), em relevo do portal norte da catedral de Ourense (segunda metade do século XII), na placa esmaltada do altar de Klosterneuburg (1181), próximo a Viena e obra de Nicolau de Verdun ${ }^{83}$.

\footnotetext{
${ }^{79}$ COUDRETTE - Le roman de Mélusine..., pp. 62-64; Gênesis III, 20 e V, 4.

${ }^{80}$ Pode-se aproximar a iluminura de um manuscrito de 1023 do De universo de Rábano Mauro (Biblioteca de Montecassino, Ms. 132, fol. 294) na qual a Mãe-Terra amamenta uma vaca e uma serpente, da iluminura de um manuscrito do século XV na qual a mulher-serpente Melusina amamenta seus filhos (BnF, Ms. fr. 24383, fol. 30 [Em linha]. [Consultado a 18 Setembro 2019]. Disponível em https://gallica.bnf.fr/ark:/12148/btv1b105258709/f63.image), versão iconográfica do texto de COUDRETTE - Le roman de Mélusine..., pp. 63 e 109. Na versão de João de ARRAS o marido termina seus dias no mosteiro de Montserrat (Mélusine, roman du XIVe siècle, p. 273), onde significativamente era cultuada uma Virgem Negra, conhecida hipóstase da Mãe-Terra.

${ }^{81}$ COUDRETTE - Le roman de Mélusine..., pp. 61-63, 70, 85; Gênesis IV, 17.

82 Gênesis IV, 8; ARRAS, João de - Mélusine, roman du XIVe siècle..., pp. 244-245, 250-251; COUDRETTE - Le roman de Mélusine..., pp. 86 e 97.

${ }^{83}$ Por desconhecer essas imagens, BONNELL, John - "The Serpent with a Human Head in Art and in Mystery Play" ..., afirma que a serpente tentadora de cabeça humana não surge antes "do século XIII ou começo do XIV" (p. 264), e considera como o mais antigo exemplo a escultura da catedral de Amiens (p. 265), contudo posterior de uma ou duas décadas à da Notre-Dame de Paris, que ele surpreendentemente também não cita.
} 
Do ponto de vista iconográfico a resposta àquela questão é simples: ao contrário do que se pensa com frequência, imagem não é mera transposição da linguagem verbal para a linguagem plástica. Hipótese desmentida, aliás, pela arte pré-histórica e de sociedades históricas ágrafas. O pensamento é constituído por imagens, e mesmo quando elas parecem se fundar em textos, escritos ou orais, nada mais fazem do que retrabalhar, realimentar e, em última análise, restituir aquela matéria original - $\imath \delta \varepsilon ́ \alpha$ etimologicamente é aquilo que se vê, é uma imagem. Mas a materialização da ideia primária em texto ou imagem plástica não segue uma trajetória ou um ritmo fixo, ela depende dos contextos históricos, ela responde a necessidades concretas ou imaginárias da sociedade que a produz.

Aquilo que a linguística e a mitologia não esclarecem, fica sugerido pela história social. No Ocidente medieval acentuadamente masculino, a depreciativa identificação serpenteEva tornou-se comum a partir do momento em que despontou certo reconhecimento do papel social da mulher. Não é casual que a mais poderosa ordem monástica dos séculos X-XII, a de Cluny, tenha tido como patronos os apóstolos Pedro e Paulo, enquanto a concorrente que a supera nos séculos XII-XIII, a ordem de Cister, tenha elegido Maria como protetora. Todavia a revalorização feminina apresentava claros limites ideológicos, impostos pelo fato de o homem ter sido criado à imagem de Deus e a mulher tão só à sua semelhança, o que sugere que naquele motivo iconográfico o réptil deixava de ser somente a tradicional representação do Diabo para duplicar-se em Eva, pois toda imagem imita algo, é reprodução dele, diz Agostinho ${ }^{84}$.

A relação serpente-Eva ganhou novo alcance na segunda metade do século XV com o surgimento da imprensa, cujo princípio básico também é especular, pois os tipos metálicos de imagem invertida aparecem em posição normal quando prensados contra uma folha de papel. Para a invenção da tipografia, Gutenberg provavelmente se inspirou na sua atividade anterior de fabricante de pequenos espelhos metálicos usados pelos peregrinos que se dirigiam a Aachen, acreditando com eles fixar as imagens das relíquias visitadas na catedral. Por meio da mesma técnica (fosse em placas de madeira ou metal) eram feitas as gravuras com que Drach, Richel e Vérard ilustravam suas publicações, em

\footnotetext{
${ }^{84} 1$ coríntios XI, 7; Apocalipse XII, 9; XX, 2; AGOSTINHO - De diversis quaestionibus (PL 40), 74, cols. 85-86, passagem usada na argumentação de mesmo sentido desenvolvida por AQUINO Tomás de - Suma Teológica, I, q.92, a.1, Vol. II, p. 619.
} 
algumas das quais aparece a serpente prosopogino. Tratava-se de todo um jogo de espelhos, mítico, moral, social, artístico, tipográfico.

Jogo que não podia, evidentemente, ficar isento da crescente misoginia ambiente Boccaccio, pela boca de um personagem, define as mulheres como "animali senza intelletto" - porque, nos termos de Descola, "os julgamentos de identidade não se exprimem somente em enunciados, são igualmente visíveis em imagens, pois figurar é, em suma, dar a ver a armação ontológica do real" ${ }^{\text {85 }}$. Uma iluminura realizada entre 1402 e 1404 para uma Bible moralisée exemplifica bem tal raciocínio. Em um lado da cena, que não conta com a presença de Adão, a serpente impõe-se a Eva pela estatura e entregalhe o fruto proibido; no outro lado, Eva, de costas para a serpente, domina Adão pela altura e entrega-lhe o fruto. Ou seja, pela forma e pelo conteúdo Eva cumpre na segunda parte da cena a mesma função que a serpente na primeira - em relação tipicamente analógica, a serpente está para Eva assim como Eva está para Adão (fig. 7).

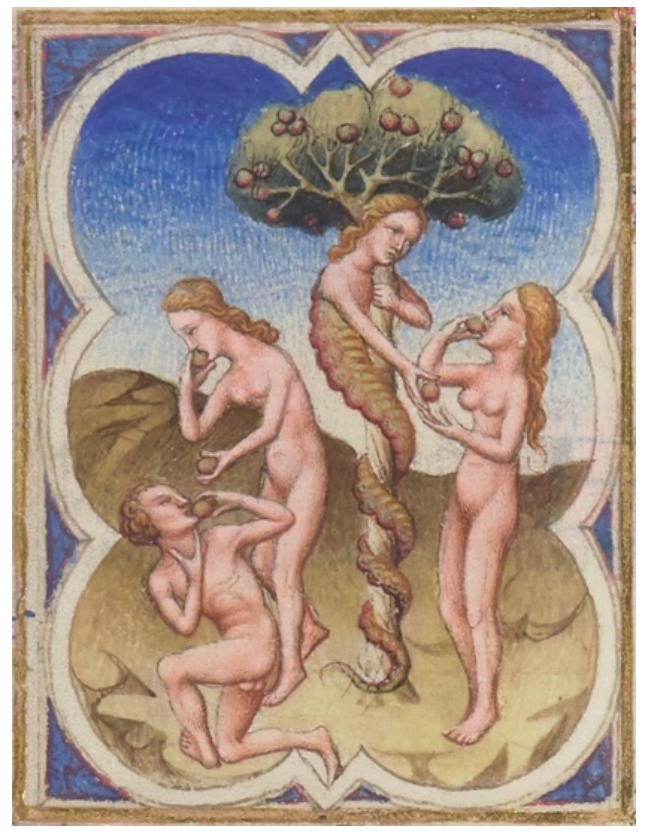

${ }^{85}$ BOCCACCIO, Giovanni - Decameron, VIII, 7. Vol. II. Ed. Mario Marti. Milão: Rizzoli, 1992, p. 559; DESCOLA, Philippe - "Manières de voir...", p. 17. As imagens da serpente com cabeça de mulher correspondem perfeitamente à definição de arte como um empreendimento que parte do quotidiano para amplificá-lo, fazer dele uma experiência mais intensa, ou seja, "tornar o vulgar, extraordinário": MORRIS, Desmond - O Macaco Criativo. Trad. Carla Morais Pires. Porto: Arte e Ciência, 2018, pp. 11-12, 272, 294. Se aceitarmos a proposta deste autor de que a primeira regra da arte é o exagero, em especial as variadas alterações corporais que transmitem "uma forte mensagem emocional" (p. 296), é inegável que no contexto sociorreligioso medieval a serpente tentadora com cabeça de mulher desempenhava esse papel. 
Fig. 7 - A relação triangular de forças, 1402-1404, Bible moralisée de Philippe le Hardi, fol. $3 \mathrm{v}^{86}$.

Outras expressivas estruturas imagéticas existiam. Com a liberdade de culto decretada no começo do século IV, multiplicaram-se os cemitérios cristãos e neles sarcófagos pétreos com a cena do Pecado original tendo somente a serpente enrolada na Árvore, como que a sintetizar os primi parentes, ausentes da figuração. O inverso também ocorria, com as cenas do Pecado sem a serpente sugerindo que ela, isto é, o mal, estava dentro dos humanos ${ }^{87}$. Daí ter sido simplesmente omitida em muitos afrescos do Pecado original nas catacumbas, por exemplo na de São Gennaro, em Nápoles, de fins do século II $^{88}$. No século VI, a mais antiga Bíblia ilustrada hoje conhecida, de origem grega, narra iconograficamente a Queda e a Expulsão em quatro episódios, no primeiro dos quais Adão e Eva seguram o fruto sem, apesar do que diz o texto sagrado logo acima da iluminura, sinal da serpente. Esta aparece apenas na quarta cena, que mostra os pais do gênero humano deixando o Éden ${ }^{89}$. No período que aqui interessa, entre outros casos a serpente continuou ausente numa iluminura francesa de princípios do século XIV, numa alemã de meados do século e noutra publicada em fins do século XV por Vérard ${ }^{90}$.

Talvez a famosa Eva do lintel do portal lateral da catedral de Autun (hoje no Museu Rolin da mesma cidade) deva sua posição horizontal e sua forma serpentina não a mera opção plástica do escultor borgonhês dos arredores de 1130, mas seja expressão, consciente ou não, da rejeição do princípio feminino. Pequenas partes do corpo do Diabo que ainda subsistem na extremidade do fragmento do lintel fazem pensar que ele também foi representado na mesma posição, reforçando a analogia entre os dois personagens. $\mathrm{O}$ fato

$86 \mathrm{BnF}, \quad$ Ms. fr. 167 [Em linha]. [Consultado a 18 Setembro 2019]. Disponível em https://gallica.bnf.fr/ark:/12148/btv1b105325870/f20.image . Cerca de trinta anos depois, o mesmo esquema iconográfico será adotado em Les très riches heures du duc de Berry, fol. $25 \mathrm{v}$.

${ }^{87}$ Segundo o Zohar, 52a, p. 268, a serpente, "morte do mundo, [...] penetrou até as mais secretas entranhas do homem", ou, numa interpretação psicanalítica, ela "encarna a psique inferior, o psiquismo obscuro, aquilo que é raro, incompreensível, misterioso" (JUNG, Carl - L'homme à la découverte de son âme: structure et fonctionnement de l'inconscient [1928-1934]. Trad. Roland Cahen-Salabelle. Genebra: MontBlanc, 1946, p. 237).

${ }^{88}$ Imagem reproduzida em ACHELIS, Hans - Die Katakomben von Neapel. Leipzig: Hiersemann, 1936, p. 44, prancha 8 .

${ }^{89}$ Die Wiener Genesis. Farbenlichtdruckfaksimile der griechischen Bildebibel aus dem 6. Jhdt. N. Chr., cod. Vindob. Theol. Grace. 31. Ed. Hans Gerstinger. Viena: Österreichisches Nationalbibliothek, 1931, pp. 1-2. Para a história deste codex purpureus, CLAUSBERG, Karl - Die Wiener Genesis: eine kunstwissenschaftliche Bilderbuchgeschichte. Frankfurt: Fischer, 1984.

${ }^{90}$ Rennes, Bibliothèque Municipale, Ms. 593, Image du monde de Gossuin de Metz, fol. 64v; Augsburgo, Universitätsbibliothek, cod. I.2.2.23, Speculum humanae salvationis, fol. 5; Le Mirouer de la redemption de l'umain lignage, fol. $2 \mathrm{v}$. 
de a imagem de Adão, hoje desaparecida, ter provavelmente sido esculpida diante da de Eva, em posição similar, não invalida o raciocínio exatamente devido ao mecanismo de contágio analógico - assim como o Diabo transforma Eva em serpente (em francês, a palavra tinha por volta de 1175 a aceção de "pessoa má") $)^{91}$, a mulher faz o mesmo com Adão. Tanto que em 1186, um relevo da entrada sul da igreja San Julián e Santa Basilisa, na localidade castelhana de Rebolledo de la Torre (a 90 km de Palencia), mostra Adão em posição mais serpentina do que a mulher que tem diante de si, do outro lado da árvore.

Portanto, não é por mera influência literária sobre a arte que se pode resolver o problema da origem da iconografia da serpente com cabeça de mulher, como fizeram John Bonnell e Henry Kelly ${ }^{92}$. A interpretação desses autores peca, a nosso ver, por tratar aquelas duas modalidades culturais como se fossem autônomas, desvinculadas da realidade social. Ao contrário, a serpente prosopogino teria sido, antes de tudo, parece-nos, reação imaginária a um fenômeno sociológico, a intensificação da misoginia clerical face ao relativo progresso da condição feminina. Se para diferentes povos em todo o mundo "o mito da criação é um instrumento darwiniano para a sobrevivência", pondera Edward Wilson ${ }^{93}$, para a civilização medieval cristã o mito do Pecado original é, entre outras coisas, instrumento para a subserviência feminina.

\footnotetext{
${ }^{91}$ REY, Alain (org.) - Dictionnaire historique de la langue française, Vol. II. Paris: Le Robert, 1995, p. $1929 b$.

92 BONNELL, John - “The Serpent with a Human Head in Art and in Mystery Play” ..., sobretudo pp. 278279 e 290-291; KELLY, Henry - "The Metamorphoses of the Eden Serpent...", em especial pp. 308-311.

${ }^{93}$ WILSON, Edward - A Conquista da Terra. A Nova História da Evolução Humana [2012]. Trad. José Vala Roberto. Lisboa: Clube do Autor, 2013, p. 16.
} 
Poder-se-ia contra-argumentar com algumas imagens nas quais a serpente prosopogino está voltada para Adão ${ }^{94}$, ou para ambos ${ }^{95}$. Ou assinalar uma Bíblia francesa iluminada em Nápoles por um discípulo de Giotto, em 1325-1340, por encomenda do rei Roberto, o sábio, na qual a serpente é representada com duas cabeças humanas, uma virada para Eva, outra para Adão (fig. 8). Mas a intenção dessas imagens não era igualitária, pelo contrário, era advertir o homem dos perigos representados pela mulher, que é a serpente. Tratava-se de postura conservadora que sem chegar a colocar a responsabilidade pelo Pecado original exclusivamente sobre os ombros de Eva, insistia que a maior parte da culpa lhe cabia a ela.

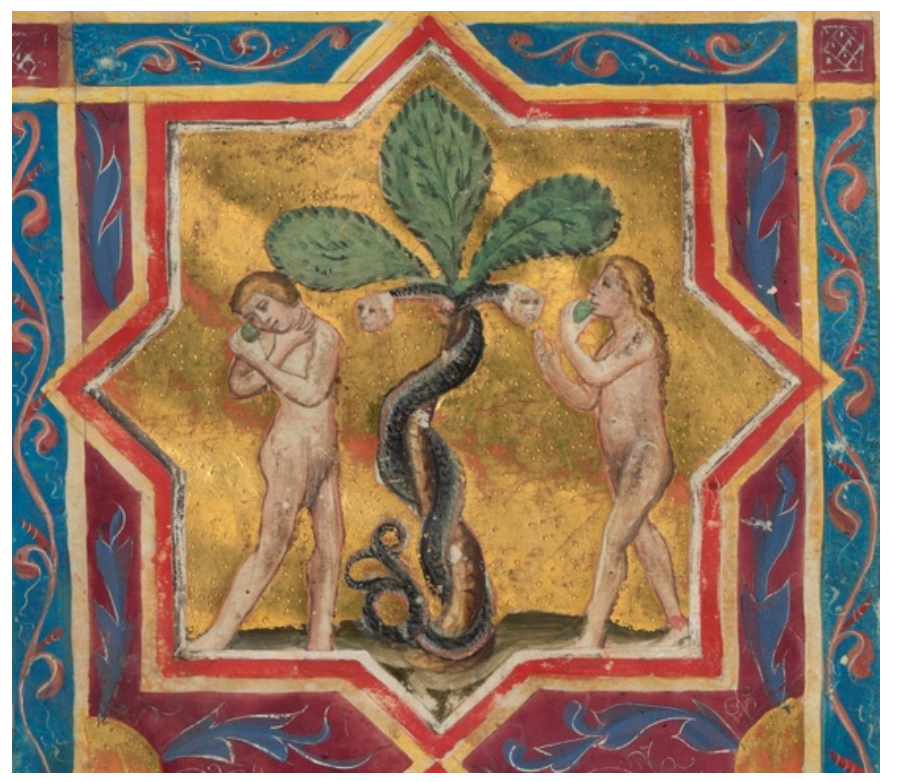

Fig. 8 - A serpente de duas cabeças, 1325-1340, Bible historiée, fol. 8v. ${ }^{96}$.

\footnotetext{
${ }^{94}$ Por exemplo, as seguintes. Um relevo da passagem do século XI ao XII na arquivolta do portal ocidental da igreja de Saint-Martin de Besse (Périgord). Um capitel de fins do XII do mosteiro catalão de San Pedro de Rodas (hoje no Museu de Cluny). Uma iluminura inglesa do já citado Compendium historiae in genealogia Christi [Em linha]. [Consultado a 18 Setembro 2019]. (Disponível em http://www.bl.uk/catalogues/illuminatedmanuscripts/ILLUMIN.ASP?Size=mid\& IllID=43367. Uma iluminura francesa de 1310-1315, BnF, nouv. acq. lat. 3255, Breviarium, fol. 1. Outra iluminura, esta de 1313-1330, Chantilly, Museu Condé, Ms. 1078-26, Ci nous dit, fol. 6. Mais uma, de fins do século XV, BnF, Ms. lat. 1171, Horae ad usum romanum, fol. 20v [Em linha]. [Consultado a 18 Setembro 2019]. Disponível em https://gallica.bnf.fr/ark:/12148/btv1b8455949b/f42.image. Uma gravura francesa de 14501460, BnF, Estampes et Photographie, Rés. 4-EA-6 [Em linha]. [Consultado a 18 Setembro 2019]. Disponível em https://gallica.bnf.fr/ark:/12148/btv1b105101210.item. Uma pintura alemã sobre madeira de 1479-1483, Retábulo de Grabow, obra de Bertram de Minden, hoje em Hamburgo, no Kunsthalle, Inv. $\mathrm{N}^{\mathrm{o}}$ HK-500. Uma xilogravura alemã pouco posterior, no Liber cronicarum de Hartmann Schedel, Nuremberg, Anton Koberger, 1493, fol. 7 [Em linha]. [Consultado a 18 Setembro 2019]. Disponível em http://daten.digitale-sammlungen.de/bsb00034024/image_ 84.).

${ }^{95}$ Como ocorre na já referida iluminura do Psalterium encomendado por Branca de Castela, fol. 10.

$96 \mathrm{BnF}$, Ms. fr. 9561 [Em linha]. [Consultado a 18 Setembro 2019]. Disponível em https://gallica.bnf.fr/ark:/12148/btv1b7200010r/f22.image. Essa serpente dupla seria reflexo da tradição
} 
A contrapartida deveria ser a fidelidade e obediência irrestritas por parte da mulher. É o que jocosamente defende um pequeno texto anônimo da primeira metade do século XIII ao afirmar que Eva foi criada a partir de um sólido osso de Adão para que os homens possam bater nas suas mulheres regularmente, três ou quatro vezes por dia de preferência. É o que pensa em 1297 o bispo Jacopo de Varazze, para quem toda esposa deve um amor total, persuadida que "ninguém é mais sábio, mais forte e mais belo que seu marido", ninguém faz ou diz coisas tão bem como ele. É o que propõe um burguês parisiense ao escrever para sua jovem esposa, em 1393, uma espécie de speculum uxorem no qual argumenta que assim como cães, pássaros e mesmo animais selvagens amam "perfeitamente seus protetores $[$ patrons] e benfeitores, $[\ldots]$ as mulheres devem ter por seus maridos um amor perfeito e publicamente demonstrado [solemnelle]"97.

A incapacidade jurídica feminina, variável conforme os locais, épocas e condições sociais, manifestava-se um pouco por toda parte. Na Inglaterra, por exemplo, se tanto a mulher solteira como a viúva podia possuir terras, prestar homenagem vassálica, fazer testamento, assinar contratos, entrar na justiça contra alguém, durante o casamento não tinha controlo sobre os bens que levara em dote ou recebera em herança depois de casada. A passagem para essa condição podia se dar à sua revelia, a não ser que tivesse condições de comprar tal direito ao seu senhor feudal, o que não era comum tendo em conta a precocidade dos casamentos na época. Pequenas eram as possibilidades de a mulher solteira exercer seus direitos e os da viúva serem acatados, como sugerem em 1215 dois artigos da Magna Carta ${ }^{98}$.

cabalista de meados do século XIII, segundo a qual "Samael assumiu a forma de Adão e Lilith a forma de Eva" (ISAAC HA-COHEN - Tratado sobre as emanações da esquerda, citado por HALPERN, Catherine; BITTON, Michèle - Lilith, l'épouse de Satan..., p. 121).

${ }^{97}$ Respectivamente, Du con qui fu fait à la besche, em Nouveau recueil complet des fabliaux, 22. Ed. Nico van den Boogard e Willem Noomen. Assen: Van Gorcum, 1988, vol. IV, pp. 13-21; Chronica civitatis Ianuensis, V, 3. Ed. Giovanni Monleone. Roma: Istituto Storico Italiano per il Medioevo, 1941, pp. 197198; Le mesnagier de Paris, I, V, 33. Ed. Georgina E. Brereton e Janet M. Ferrier, trad. Karin Ueltschi. Paris: Le Livre de Poche, 1994, pp. 182-185.

${ }_{98}^{98}$ POWER, Eileen - Medieval Women..., pp. 30-32; Magna Carta, §7-8. Ed. e trad. James C. Holt. in HOLT, James C. - Magna Carta [1965]. Cambridge: Cambridge University Press, 1976, pp. 318-321. 
O progresso nessa matéria, mais sentido no Norte europeu ${ }^{99}$, refletiu-se na língua, facto social que exprime a visão de mundo de seus falantes, ensinou Saussure. É instrutivo que "serpente" tenha sido forma gramatical masculina no antigo alto alemão (slango) e no médio alto alemão (slange), portanto ao longo de seis séculos, antes de passar no médio baixo alemão para os dois gêneros e depois se estabilizar no século XVI como Schlange, palavra feminina ${ }^{100}$. Na iconografia, a resposta misógina às transformações sociais gerou intensa produção do tipo de imagem que estamos estudando (do qual só podemos citar aqui alguns testemunhos), mais precoce nos atuais territórios franceses ${ }^{101}$, mais tardia nos alemães $^{102}$ e holandeses ${ }^{103}$.

À luz disso tudo, percebe-se que a riqueza à primeira vista insuspeita da gravura de Antoine Vérard fundamenta-se em uma analogia de proporção a oito termos, seis explícitos, dois implícitos, porém provavelmente tão atuantes para os observadores contemporâneos quanto os demais - Adão está para Eva assim como o cervo para o unicórnio, a serpente para o macaco, Lilith para Melusina.

\footnotetext{
${ }^{99}$ Talvez não seja casual que o poema de Coudrette sobre Melusina tenha tido ampla repercussão na região, com a tradução alemã de Ringoltingen conhecendo 80 edições de 1478 a 1587, além de traduções inglesas, flamengas, dinamarquesas e suecas, cf. HARF-LANCNER, Laurence - "Introduction". in COUDRETTE - Le roman de Mélusine..., p. 35.

${ }^{100}$ GRIMM, Jacob e Wilhelm - Deutsches Wörterbuch [1854]. Munique: Deutscher Taschenbuch, 1984, vol. XV, p. 440; DWDS. Das Wortauskunftssystem zur deutschen Sprache in Geschichte und Gegenwart [Em linha]. [Consultado a 18 Setembro 2019]. Disponível em https://www.dwds.de/wb/Schlange.

${ }^{101}$ Relevo da base do pilar da Porta da Virgem das catedrais de Paris (1210-1220) e de Amiens (c.1230), vitrais da Sainte-Chapelle (1245-1248), da catedral de Tours (c.1255-1260) e da igreja Saint-Étienne de Mulhouse (século XIV), iluminuras da Bible moralisée (1235-1245, Oxford, Bodleian Library, Ms. Bodley 270b, fol. 7v), da Bíblia de Acra (1250-1254, Arsenal, Ms. 5211 Rés., fol. 3v), de uma Biblia procedente do norte francês (c.1280-1290, British Library, Add. Ms. 11639, fol. 520v).

${ }^{102}$ Caso de estampas para Bíblias em vernáculo impressas em Bamberg, Albrecht Pfister, c.1462, fol. 5v; Colônia, Heinrich Quentell, c.1478, fol. 2; Lübeck, Steffen Arndes, 1474, fol. 8; Estrasburgo, Johann Grüninger, 1485, fol. 2v. Caso de gravuras para textos de diferentes naturezas, em latim ou alemão, por exemplo THERAMO, Jacobus de - Consolatio peccatorum. Augsburgo: Günther Zainer, 1472, fol. 26v; Spiegel menschlicher Behaltnis. Basileia: Bernhard Richel, 1476, fol. 2. Caso de desenhos como os que ornam a versão alemã do mais difundido apócrifo adâmico: Viena, Österreichische Nationalbibliothek, Cod. Vindob. 2980, Lutwins Adam und Eva, fol. 13v. Ou de telas como a que Hugo van der Goes dedicou ao Pecado original em torno de 1479, hoje em Viena, Kunsthistorisches Museum, Inv. 5822a.

${ }^{103}$ Por exemplo, iluminuras como as confeccionadas em Bruges para a Bible moralisée, c.1450 (British Library, Add. Ms. 15248, fol. 17), o Arenberg Hours decorado por Willem Vrelant em 1462-1464 (J. Paul Getty Museum, Ms. Ludwig IX 8, fol. 137) ou La pénitence d'Adam pintada pelo Mestre de Bruges entre 1472 e 1484 (BnF, Ms.fr. 1837, fol. 6); esculturas, como a realizada em 1470-1480 em madeira, hoje no Metropolitan Museum, Inv. 55.116.2; pinturas, como as feitas por Bosch em dois paineis laterais de trípticos, um do Juizo Final, de 1504 (Viena, Gemäldegalerie der Akademie, Inv. GG-579), outro do Carro de feno, de 1512-1515 (Museu do Prado, Inv. P002052).
} 


\section{Referências bibliográficas}

\section{Fontes primárias}

\subsection{Fontes manuscritas}

Augsburgo, Universitätsbibliothek, cod. I.2.2.23, Speculum humanae salvationis.

Baltimore, Walters Art Gallery, Ms. W.34, Saltério Carrow.

Carpentras, Biblioteca Inguimbertine, Ms.622, Cas des nobles hommes et femmes.

Chantilly, Museu Condé, Ms. 28, Histoire extraite de la Bible et Apocalypse, en français.

Chantilly, Museu Condé, Ms. 65/1284, Les très riches heures du duc de Berry.

Chantilly, Museu Condé, Ms. 1078-26, Ci nous dit.

La Haye, Museum Meermanno-Westreenianum, Ms. 10 A 12, La Cité de Dieu.

Londres, British Library, Royal Roll 14 B IX, Compendium historiae in genealogia Christi.

Londres, British Library, Royal 14 C IX, Polychronicon.

Londres, British Library, Royal I D I, Bíblia de William de Devon.

Londres, British Library, Add. Ms. 11639, Bíblia hebraica.

Londres, British Library, Add. Ms. 15248, Bible moralisée.

Londres, British Library, Add. Ms. 18850, Bedford Hours.

Londres, British Library, Add. Ms. 47682, Bíblia de Holkham.

Londres, British Library, Yates Thompson Ms. 14, Saltério de Saint-Omer.

Londres, College of Arms, Muniment Room 18-19, Mapa da abadia de Evesham.

Los Angeles, J. Paul Getty Museum, Ms. Ludwig IX 8, Arenberg Hours.

Montecassino, Biblioteca monástica, Ms. 132, De Universo.

Oxford, Bodleian Library, Ms. Auct. D. 3. 2, Biblia.

Oxford, Bodleian Library, Ms. Bodley 270b, Bible moralisée. 
Oxford, Bodleian Library, Ms. Bodley 764, Bestiarium.

Paris, Bibliothèque de l'Arsenal, Ms. 1186, Psalterium (dito de Branca de Castela).

Paris, Bibliothèque de l'Arsenal, Ms. 5076, Trésor de sapience.

Paris, Bibliothèque de l'Arsenal, Ms. 5211 Rés., Bíblia de Acra.

Paris, BnF, Ms. fr. 21, La Cité de Dieu.

Paris, BnF, Ms. fr. 166, Bible moralisée de Philippe le Hardi.

Paris, BnF, Ms.fr. 1837 La pénitence d'Adam.

Paris, BnF, Ms. fr. 9561, Bible historiée.

Paris, BnF, Ms. fr. 13096, Apocalypse en françois.

Paris, BnF, Ms. fr. 24383, Roman de Mélusine.

Paris, BnF, Ms. lat. 511, Speculum humanae salvationis.

Paris, BnF, Ms. lat. 1171, Horae ad usum romanum.

Paris, BnF, nouv. acq. lat. 3255, Breviarium.

Rennes, Bibliothèque Municipale, Ms. 593, Image du monde.

Roma, Biblioteca Apostolica Vaticana, Ms. Pal. lat. 1995, Livre des bonnes mours.

São Petersburgo, Rossiiskaia Natsionalnaia Biblioteka, Lat. Q. v. I. 126, Livre d'Heures de Louis d'Orléans.

Toledo, catedral, Ms. 1, Bíblia de São Luís.

Valenciennes, Bibliothèque Municipale, Ms. 101, Aviarium.

Viena, Österreichische Nationalbibliothek, Cod. Vindob. 2980, Lutwins Adam und Eva.

\subsection{Fontes impressas}

AGOSTINHO - De diversis quaestionibus. in Patrologia Latina (PL) 40, cols. 11-100. AGOSTINHO - Enarrationes in Psalmi. in PL 36, cols. 67-1028. 
AMBRÓSIO - Exameron. I sei giorni della creazione. Ed. Carl Schenkl, trad. Gabrielle Banterle. Milão / Roma: Biblioteca Ambrosiana / Città Nuova, 1979 (Opera omnia di Sant'Ambrogio, 1).

Gli Apocrifi del Nuovo Testamento. Ed. e trad. Mario Erbetta. $2^{\mathrm{a}}$ ed. Gênova: Marietti, 1983-1992, 3 vols.

ARRAS, Jean d' - Mélusine, roman du XIV siècle. Ed. Louis Stouff. Genebra: Slatkine, 1974.

AUGUSTODUNENSE, Honorius - Speculum Ecclesiae. in PL 172, cols. 807-1108.

AUXERRE, Goffredo di - Super Apocalypsim. Ed. Ferruccio Gastaldelli. Roma: Edizioni di storia e de letteratura, 1970 (Temi e testi, 17).

BEAUVAIS, Pierre de - Bestiaire. Ed. Charles Cahier; Arthur Martin. in Mélanges d'archéologie, d'histoire et de littérature. Paris: Poussielgue-Rusand, 1851, Vol. II, pp. 106-232; 1853, Vol. III, pp. 203-288.

BEAUVAIS, Vincent de - Speculum naturale. Graz: Akademische Druck- u. Verlagsanstalt, 1964.

BERNARDUS - Apologia ad Guillelmum abbatem. Ed. Jean Leclercq e Henri M. Rochais. Roma: Editiones Cistercienses, 1963 (S. Bernardi Opera, III), pp. 81-108.

Le bestiaire (Oxford, Bodleian, ms. Ashmole 1511). Trad. Marie-France Dupuis e Sylvain Louis. Paris: Philippe Lebaud, 1988.

Bestiaires du Moyen Age. Ed. trad. Gabriel Bianciotto. Paris: Stock, 1980.

The Bestiary. A book of beasts (Cambridge University Library, Ms. Ii.4.26). Trad. Terence H. White. Nova Iorque: Putnam, 1960.

Bibel. Bamberg: Albrecht Pfister, s.d. [c.1462].

Bibel. Colônia: Heinrich Quentell, s.d. [c.1478].

Bibel. Estrasburgo: Johann Grüninger, 1485.

Bibel. Lübeck: Steffen Arndes, 1474.

Bible en francoiz historiee. Paris: Antoine Vérard, s.d. [c.1505]. Exemplares BnF, Rés. G-A-22; Metropolitan Museum of Art, Harris Brisbane Dick Fund, 1924, 24.16.1.

Bible en francois hystoriee. Paris: Antoine Vérard, s.d. [c.1510]. Exemplares BnF, Rés. A-273; Metropolitan Museum of Art, Elisha Whittelsey Fund, 1951, 51.548.

Bible en francois hystoriee. Paris: Barthélemy Vérard, 1514. Exemplar Bibliothèque de l'Arsenal FOL-T-142. 
Bible historiee. Paris: Antoine Vérard, s.d. [c.1498-1499]. Exemplar BnF, Rés. A-270.

Biblia Vulgata. Ed. Alberto Colunga e Laurentio Turrado. 12 ed. Madrid: BAC, 2005.

BINGEN, Hildegardis de - Causae et curae. Ed. Paul Kaiser. Leipzig: Teubner, 1903.

BOCCACCIO, Giovanni - Decameron. Ed. Mario Marti. Milão: Rizzoli, 1992, 2 vols.

BOCCACCIO, Giovanni - Von Etlichen Frowen [tradução alemã do De claribus mulieribus]. Augsburgo: Anton Sorg, 1479.

BRANT, Sébastian - Das Narrenschiff. Basileia: Johann Bergmann von Olpe, 1494.

BRANT, Sébastian - La nef des folz du monde. Trad. Pierre Rivière e Jakob Locher. Paris: Vérard, 1497.

BRANT, Sébastian - Stultiferae naves sensus animosque trahentes mortis in exitium. Trad. Josse Bade. Burgos: Fadrique Biel de Basilea, 1500.

BRANT, Sébastian - Stultiferae naves sensus animosque trahentes mortis in exitium. Trad. Josse Bade. Paris: Thielman Kerver, 1500.

CAMBRAI, Geraldo de - De principis instructione. Ed. George F. Warner. Wiesbaden: Kraus Reprint, 1964 (Rerum Britannicarum Medii Aevi Scriptores, 21-VIII).

La caverna dei tesori. Ed. Margaret Dunlop Gibson, trad. Antonio Battista e Bellarmino Bagatti. Jerusalém: Franciscan Priting Press, 1979 (Studium Biblicum Franciscanum. Collectio Minor, 26).

La caverne des trésors. Les deux recensions syriaques. Ed. Carl Bezold, trad. Su-Min Ri. Louvain: Peeters, 1987 (Corpus Scriptorum Christianorum Orientalium, Scriptores syri, 208).

La caverne des trésors. Version géorgienne. Ed. Ciala Kourcikidzé, trad. Jean-Pierre Mahé. Louvain: Peeters, 1992 (Corpus Scriptorum Christianorum Orientalium, Scriptores Iberici, 24).

COLONNE, Guido della - Historia destructionis Troiae. Ed. Nathaniel E. Griffin. Cambridge (Mass.): Medieval Academy of America, 1936.

Il combattimento di Adamo. Ed.e trad. Antonio Battista e Bellarmino Bagatti. Jerusalém: Franciscan Printing Press, 1982 (Studium Biblicum Franciscanum Collectio Minor, 29).

COMESTOR, Pedro - Historia scholastica. Liber Genesis. in PL 198, cols. 1055-1142.

COUDRETTE - Le roman de Mélusine. Ed. Eleanor Roach, trad. Laurence HarfLancner. Paris: GF-Flammarion, 1993. 
DAMIANO, Pedro - De bono religiosi status. in PL 145, cols. 763-792.

The Fathers According to Rabbi Nathan. Abot de Rabbi Nathan Version B. Ed.

Solomon Schechter, trad. Anthony J. Saldarini. Leiden: Brill, 1975.

HISPANO, Pedro - Thesaurus pauperum. in Obras médicas de Pedro Hispano. Edtrad. Maria Helena da Rocha Pereira. Coimbra: Fundação Calouste Gulbenkian / Universidade de Coimbra, 2014, pp. 78-301.

LANGLAND, William de - The Book Concerning Piers the Plowman. Ed. Rachel Attwater, trad. Donald e Rachel Attwater. Nova Iorque: Dutton, 1957.

LATINI, Brunetto - Le livre du trésor. Ed. Francis Carmody, trad. Bernard Ribémont e Silvère Menegaldo. Paris: Honoré Champion, 2013 (Traductions des classiques du Moyen Âge, 94), vol. I.

Libellus de natura animalium / Le proprietà degli animali. Ed. Paola Navone, trad. Annamaria Carrega. Gênova: Costa e Nolan, 1983.

LÚLIO, Raimundo - Livro das bestas. Ed. Marina Gustá, trad. Cláudio Giordano. São Paulo: Loyola-Giordano, 1990.

LYON, Eucário de - Liber formularum spiritalis intelligentiae. in PL 50, cols. 727-772.

MAP, Gautier - Contes pour les gens de cour. Ed. Christopher N. L. Brooke e Roger A. B. Mynors, trad. Alan K. Bate. Turnhout: Brepols, 1993.

Le mesnagier de Paris. Ed. Georgina E. Brereton e Janet M. Ferrier, trad. Karin Ueltschi. Paris: Le Livre de Poche, 1994.

Midrach Rabba. Genèse Rabba. Ed. Moseh A. Mirkin, trad. Bernard Maruani e Albert Cohen-Arazi. Paris: Verdier, 1987.

MILTON, John - Paradise Lost. Ed. John Leonard. Londres: Penguin, 2003.

Le Mirouer de la redemption de l'umain lignage. Paris: Antoine Vérard, 1493-1494.

Nouveau recueil complet des fabliaux. Ed. Nico van den Boogard e Willem Noomen. Assen: Van Gorcum, 1983-1998, 10 vols.

ORÍGENES - Homélies sur le Cantique des cantiques. Ed. Willem A. Baehrens, trad. Olivier Rousseau. Paris: Cerf, 1954 (Sources Chrétiennes, 37).

The Old Testament Pseudepigrapha. Ed. James H. Charlesworth. Londres / Nova Iorque: Darton, Longman \& Todd / Doubleday, 1983-1985, 2 vols.

Physiologus latinus. Versio B. Ed. Francis J. Carmody. Paris: Droz, 1939.

PSEUDO-BEDA - Quaestiones super Genesim. in PL 93, cols. 233-362. 
RINGOLTINGEN, Thüring von - Melusine. Basileia: Bernhard Richel, 1474.

RINGOLTINGEN, Thüring von - Melusine. Augsburgo: Anton Sorg, 1485.

S.a. [Maître des bordures des Pères de l'Église] - Le Péché originel. S.1, s.ed., s.d [14501460]. Exemplar BnF, Estampes et Photographie, Rés. 4-EA-6.

SAINT-VICTOR, Pseudo-Hugo de - De bestiis et aliis rebus. in PL 177, cols. 13-164.

SCHEDEL, Hartmann - Liber cronicarum. Nuremberg: Anton Koberger, 1493.

SEVILHA, Isidoro de - Etimologías. Ed. Wallace M. Lindsay, trad. José Oroz Reta e Manuel-Antonio Marcos Casquero. Madrid: BAC, 2009.

Speculum humanae salvationis. Ed. Jules Lutz e Paul Perdrizet. Mulhouse: Meininger, 1907, vol. I.

Speculum humanae salvationis. Augsburgo: Günther Zainer, s.d. [c.1473].

Spiegel menschlicher Behältnis. Augsburgo: Anton Sorg, 1476.

Der Spiegel menschlicher Behältnis. Spira: s.ed. [Peter Drach], s.d. [c.1480].

Targum du Pentateuque. Genèse. Ed. e trad. Roger Le Déaut. Paris: Cerf, 1978 (Sources Chrétiennes, 245).

TERTULIANO - Adversus Judaeos. Ed. Alöis Gerlo. Turnhout: Brepols, 1954 (Corpus Christianorum. Series Latina, 2).

THAUN, Philippe - Le bestiaire, vv 1901-1902. Ed. Emmanuel Walberg. Rungis: Maxtor, 2017.

THERAMO, Jacobus de - Consolatio peccatorum. Augsburgo: Günther Zainer, 1472.

TILBURY, Gervásio de - Otia imperialia. Ed. e trad. Shelagh E. Banks e James W. Binns. Oxford: Clarendon, 2002.

TOMÁS DE AQUINO - Suma teológica. Ed. Leonina, trad. dir. Gabriel Galache e Danilo Mondoni. São Paulo: Loyola, 2002-2006, 9 vols.

VARAZZE, Jacopo de - Chronica civitatis Ianuensis. Ed. Giovanni Monleone. Roma: Istituto Storico Italiano per il Medioevo, 1941.

VARAZZE, Jacopo de - Legenda Áurea. Ed. Theodor Graesse, trad. Hilário Franco Júnior. São Paulo: Companhia das Letras, 2003.

Vita Adae et Evae. Ed. Jean-Pierre Pettorelli. Turnhout: Brepols, 2012 (Corpus Christianorum Series Apocryphorum, 18-19). 
Die Wiener Genesis. Farbenlichtdruckfaksimile der griechischen Bildebibel aus dem 6. Jhdt. N. Chr., cod. Vindob. Theol. Grace. 31. Ed. Hans Gerstinger. Viena: Österreichisches Nationalbibliothek, 1931.

Zohar. Ed. Yehouda L. Achlag, trad. Charles Mopsik. Paris: Verdier, 1988.

\section{Obra de referência}

BASKIN, Judith R. - The Cambridge Dictionary of Judaism and Jewish Culture. Nova Iorque: Cambridge University Press, 2011.

DWDS. Das Wortauskunftssystem zur deutschen Sprache in Geschichte und Gegenwart [Em linha]. [Consultado a 18 Setembro 2019]. Disponível em https://www.dwds.de.

Grande Dicionário Houaiss da Língua Portuguesa. Lisboa: Círculo de Leitores, 2015, 6 vols.

GRIMM, Jacob e Wilhelm - Deutsches Wörterbuch [1854]. Munique: Deutscher Taschenbuch, 1984, 33 vols.

REY, Alain (org.) - Dictionnaire historique de la langue française. Paris: Le Robert, 1995, 2 vols.

\section{Estudos}

ACHELIS, Hans - Die Katakomben von Neapel. Leipzig: Hiersemann, 1936.

BITTON, Michèle - "Lilith ou la première Ève. Un mythe juif tardif". Archives de sciences sociales des religions 71 (1990), pp. 113-136.

BLOCH, Howard - Medieval Misogyny and the Invention of Western Romantic Love. Chicago: Chicago University Press, 1991.

BONNELL, John K. - "The Serpent with a Human Head in Art and in Mystery Play". American Journal of Archaeology 21 (1917), pp. 255-291.

BRIL, Jacques - Lilith ou la Mère obscure [1984]. 2a ed. Paris: Payot, 1991.

CAMPBELL, Joseph - As Máscaras de Deus [1964]. Vol.III. Mitologia Ocidental. Trad. Carmen Fischer. São Paulo: Palas Athena, 2004.

CLAUDIN, Anatole - Histoire de l'imprimerie en France au XV et XVI siècle. Paris: Imprimerie Nationale, 1901.

CLAUSBERG, Karl - Die Wiener Genesis: eine kunstwissenschaftliche Bilderbuchgeschichte. Frankfurt: Fischer, 1984. 
CLIER-COLOMBANI, Françoise - La fée Mélusine au Moyen Âge. Images, mythes et symboles. Paris: Le Léopard d'Or, 1991.

CROSS, Tom P. - "Celtic Elements in Lanval and Graelent". Modern Philology 12 (1915), pp. 4-5.

CURTIUS, Ernst R. - Literatura Europeia e Idade Média Latina [1948]. Trad. Paulo Rónai e Teodoro Cabral. São Paulo: Edusp / Hucitec, 1996.

DAN, Joseph - "Samael, Lilith, and the Concept of Evil in Early Kabbalah". Association for Jewish Studies Review 5 (1980), pp. 17-40.

DESCOLA, Philippe - La fabrique des images. Visions du monde et formes de la représentation. Paris: Musée du Quai Branly / Somogy, 2010.

DESCOLA, Philippe - La Nature domestique. Symbolisme et praxis dans l'écologie des Achuars. Paris: Maison des Sciences de l'Homme, 1996.

DESCOLA, Philippe - Par-delà nature et culture. Paris: Gallimard, 2005.

ECO, Umberto - "Sobre os espelhos" [1985]. Trad. Helena Domingos. in Sobre os espelhos e outros ensaios. Lisboa: Relógio d'Água, 2016, pp. 15-43.

EINHORN, Jürgen W. - Spiritalis Unicornis. Das Einhorn als Bedeutungsträger in Literatur und Kunst des Mittelalters. Munique: Fink, 1976.

FOURNIÉ, Eléonore - "Catalogue des éditions de la Bible historiale". L'Atelier du Centre de Recherches Historiques. Revue électronique du CRH 03.2 (2009) [Em linha]. [Consultado a 18 Setembro 2019]. Disponível em http://journals.openedition.org/acrh/1839.

FRANCO JÚNIOR, Hilário - Os três dedos de Adão. Ensaios de mitologia medieval [1996]. 2a ed. São Paulo: Edusp, 2010.

FRANCO JÚNIOR, Hilário - "Similibus simile cognoscitur. O pensamento analógico medieval". Medievalista 14 (julho-dezembro 2013). [Em linha]. [Consultado a 18 Setembro 2019]. Disponível em http://www2.fcsh.unl.pt/iem/ medievalista/MEDIEVALISTA14/ junior1402.html.

FROMAGE, Henri - "Recherches sur Mélusine". Bulletin de la Société de Mythologie Française 86 (1972), pp. 42-75.

GASTER, Theodor H. - Myth, Legend and Custom in the Old Testament [1969]. $2^{\mathrm{a}}$ ed. Nova Iorque: Harper, 1975.

GINZBERG, Louis - The Legends of the Jews. Vol. V.Filadélfia: The Jew Society of America, 1925 
GRAVES, Robert; PATAI, Raphaël - Les mythes hébreux [1963]. Trad. Jean-Paul Landais. Paris: Fayard, 1987.

HALPERN, Catherine; BITTON, Michèle - Lilith, l'épouse de Satan. Paris: Larousse, 2010.

HARF-LANCNER, Laurence - Les fées au Moyen Âge. Paris: Honoré Champion, 1984.

HOFFELD, Jeffrey M. - “Adam's Two Wives". The Metropolitan Museum of Art Bulletin 26 (1968), pp. 430-440.

HOLT, James C. - Magna Carta [1965]. $3^{\text {a }}$ ed. Cambridge: Cambridge University Press, 1976.

JANSON, Horst W. - Apes and Ape Lore in the Middle Age and the Renaissance. Londres: Warburg Institute-University of London, 1952.

JONES, Charles - Grammatical Gender in English, 950 to 1250. Londres: Croom Helm, 1988.

JOSSUA, Jean-Pierre - La licorne: histoire d'un couple. Paris: Cerf, 1985.

JUNG, Carl - L'homme à la découverte de son âme: structure et fonctionnement de l'inconscient [1928-1934]. Trad. Roland Cahen-Salabelle. Genebra: Mont-Blanc, 1946.

KELLY, Henry A. - "The Metamorphoses of the Eden Serpent during the Middle Ages and Renaissance". Viator 2 (1971), pp. 301-327.

LECLERCQ-KADANER, Jacqueline - "De la Terre-Mère à la Luxure. À propos de la migration des symboles". Cahiers de Civilisation Médiévale 18 (1975), pp. 37-43.

LECOUTEUX, Claude - Mélusine et le Chevalier au Cygne. Paris: Payot, 1982.

LE GOFF, Jacques - "Mélusise maternelle et défricheuse" [1971]. in LE GOFF, Jacques - Pour un autre Moyen Âge. Paris: Gallimard, 1977, pp. 307-331.

LÉVI, Israel - “Lilit et Lilin”. Revue des études juives 68 (1914), pp. 15-21.

MACFARLANE, John - Antoine Vérard [1900]. Genebra: Slatkine, 1971.

MORRIS, Desmond - O Macaco Criativo. Três Milhões de Anos de Arte [2013]. Trad. Carla Morais Pires. Porto: Arte e Ciência, 2018.

MOSES, Elizabeth - "Über eine Kölner Handschrift der Mischneh Thora des Maimonides”. Zeitschrift für bildende Kunst 60 (1926-1927), pp. 71-76.

PAGELS, Elaine - Adam, Eve et le serpent [1988]. Trad. Michèle Miech Chatenay. Paris: Flammarion, 1989. 
POWER, Eileen - Medieval Women [1975]. Cambridge: Cambridge University Press, 1997.

SCHNYDER, André; RAUTENBERG, Ursula - Thüring von Ringoltingen Melusine (1456). Nach dem Erstdruck Basel: Richel um 1473/74. Wiesbaden: Reichert, 2006.

SCHOLEM, Gershom - "Lilith". in Encyclopaedia Judaica. Vol.XI. Nova Iorque: Macmillan, 1971, cols. 245-249.

SCHOLEM, Gershom - Les origines de la Kabbale. Paris: Aubier-Montaigne, 1966.

SHERESHEVSKY, Esra - "Hebrew Traditions in Peter Comestor's Historia scholastica". Jewish Quarterly Review 59 (1969), pp. 268-289.

TOMPKINS, Ptolemy - O Macaco na Arte [1994]. Trad. Isabel Motta. Lisboa: Quetzal, 1994.

TRAPP, Joseph B. - "The Iconography of the Fall of Man". in PATRIDES, Constantinos A. (ed.) - Approaches to Paradise Lost. Londres: Edward Arnold, 1968, pp. 223-265.

WILSON, Edward - A Conquista da Terra. A Nova História da Evolução Humana [2012]. Trad. José Vala Roberto. Lisboa: Clube do Autor, 2013.

WINN, Mary B. - Anthoine Vérard. Parisian publisher, 1485-1512. Genebra: Droz, 1997.

ZEEGERS-VANDER VORST, Nicole - "Satan, Ève et le serpent chez Théophile d'Antioche". Vigiliae Christianae 35 (1981), pp. 152-169.

ZELDENRUST, Lydia - "Serpent or Half-Serpent? Bernhard Richel's Melusine and the Making of a Western European Icon”. Neophilologus 100 (2016), pp. 19-41.

\section{COMO CITAR ESTE ARTIGO}

\section{Referência electrónica:}

FRANCO JÚNIOR, Hilário - “A serpente, espelho de Eva. Iconografia, analogia e misoginia em fins da Idade Média”. Medievalista 27 (Janeiro - Junho 2020). [Em linha]. [Consultado dd.mm.aaa].

http://www2.fcsh.unl.pt/iem/medievalista/MEDIEVALISTA27/hilario2705.html ISSN 1646-740X. 


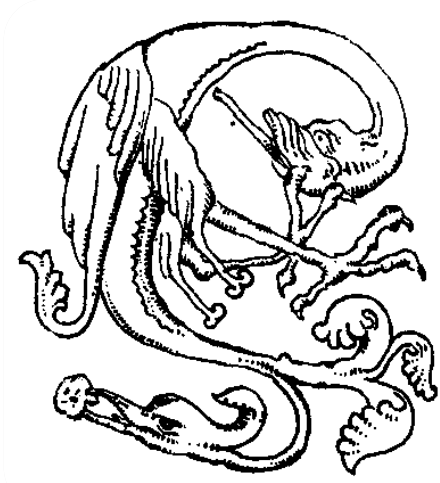

